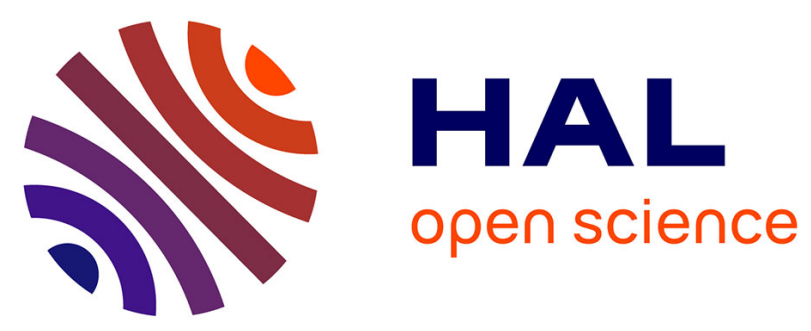

\title{
An anti-Abeta single-chain variable fragment prevents amyloid fibril formation and cytotoxicity by withdrawing Abeta oligomers from the amyloid pathway
}

Marta Marín-Argany, Geovanny Rivera-Hernández, Joaquim Martí, Sandra Villegas

\section{To cite this version:}

Marta Marín-Argany, Geovanny Rivera-Hernández, Joaquim Martí, Sandra Villegas. An antiAbeta single-chain variable fragment prevents amyloid fibril formation and cytotoxicity by withdrawing Abeta oligomers from the amyloid pathway. Biochemical Journal, 2011, 437 (1), pp.25-34. 10.1042/BJ20101712 . hal-00600758

\section{HAL Id: hal-00600758 https://hal.science/hal-00600758}

Submitted on 16 Jun 2011

HAL is a multi-disciplinary open access archive for the deposit and dissemination of scientific research documents, whether they are published or not. The documents may come from teaching and research institutions in France or abroad, or from public or private research centers.
L'archive ouverte pluridisciplinaire HAL, est destinée au dépôt et à la diffusion de documents scientifiques de niveau recherche, publiés ou non, émanant des établissements d'enseignement et de recherche français ou étrangers, des laboratoires publics ou privés. 


\title{
An anti-A $\beta$ single-chain variable fragment prevents amyloid fibril formation and cytotoxicity by withdrawing $A \beta$ oligomers from the amyloid pathway
}

\author{
Marta Marín-Argany $^{* 1}$, Geovanny Rivera-Hernández ${ }^{* 1}$, Joaquim Martí ${ }^{\dagger}$ \& Sandra Villegas ${ }^{* 2}$ \\ *Departament de Bioquímica i Biologia Molecular, and 'Departament de Inmunologia, Biología \\ Cel·lular i Fisiologia, Universitat Autònoma de Barcelona, 08193 Cerdanyola del Vallès, Spain
}

Short Title: An anti-A $\beta$ scFv changes the $\mathbf{A} \beta$ aggregation pathway

A $\beta$ immunotherapy has been revealed as a hopeful tool in Alzheimer's disease treatment. In contrast to complete antibodies, the administration of single-chain variable Fragments (scFv) produces neither meningoencephalitis nor cerebral hemorrhage. Here, the recombinant expression of scFv-h3D6, a derivative of an antibody specific for $A \beta$ oligomers, is presented, as well as the subsequent proof of its capability to recover the toxicity induced by the $A \beta_{1-42}$ peptide in the SH-SY5Y neuroblastoma cell-line. To gain insight into the conformational changes underlying the prevention of $\mathrm{A} \beta$ toxicity by this antibody fragment, the conformational landscape of scFv-h3D6 upon temperature perturbation is also described. Heating the native state does not lead to any extent of unfolding but rather directly to a $\beta$-rich intermediate state which initiates an aggregation pathway. This aggregation pathway is not an amyloid fibril pathway, as is that followed by the $A \beta$ peptide, but rather a worm-like fibril pathway which, noticeably, turns out to be non-toxic. On the other hand, this pathway is thermodynamically and kinetically favored when the scFv-h3D6 and $A \beta_{1-42}$ oligomers form a complex in native conditions, explaining how the scFv-h3D6 withdraws $A \beta_{1-42}$ oligomers from the amyloid pathway. To our knowledge, this is the first description of a conformational mechanism by which a scFv prevents $A \beta$-oligomer cytotoxicity.

Key words: ScFv, Immunotherapy, Alzheimer's disease, Worm-like fibrils, Aggregation, A $\beta$ peptide.

\footnotetext{
${ }^{1}$ These authors made equally important contributions to this study.

${ }^{2}$ To whom correspondence should be addressed (e-mail sandra.villegas@uab.cat).
}

Abbreviations used: AD, Alzheimer's disease; ANS, 1,8-Anilinonaphthalenesulfonate; APP, Amyloid Precursor Protein; CAA, Cerebral Amyloid Angiopathy; IMAC, Immobilized Metal Affinity Chromatography; MTT, 3-[4,5-dimethylthiazol-2-yl]-2,5-diphenyl tetrazolium bromide; scFv, singlechain variable Fragment; TEM, Transmission Electron Microscopy; TEV, Tobacco Etch Virus; ThT, Thioflavin T; WL, Worm-Like. 


\section{INTRODUCTION}

Since the first report of neurotoxicity induced by a fragment of APP (which included the Cterminal 105 residues) [1], increasing lines of evidence suggest that soluble $A \beta$ oligomers are the cause of the synapse loss and neuronal injury characteristic of Alzheimer's disease (AD) [2]. Concretely, it has been seen that certain cognitive impairments appear before amyloid deposits are formed [3]. Additionally, the severity of cognitive deficits correlates with the levels of soluble $A \beta$ and not with the presence of amyloid plaques [4]. These observations indicate that neurodegeneration may begin prior to, and is not the result of, amyloid deposition. Accordingly, the need exists for new therapies capturing soluble $A \beta$-oligomers rather than amyloid fibrils.

Naturally occurring antibodies against the A $\beta$ peptide (39-43 amino-acids long) are present in human cerebrospinal fluid and in the plasma of healthy individuals, but are significantly lower in $A D$ patients, suggesting that this disorder may have an immunodeficient basis [5]. The first descriptions regarding the therapeutic potential of anti- $\mathrm{A} \beta$ peptide antibodies were based on the inhibition of in vitro fibrillation, and on the prevention of neurotoxicity in cell culture, of the $A \beta_{1-40}$ peptide [6]. The demonstration of the effectiveness of $\mathrm{A} \beta$ immunotherapy in vivo was obtained in the PDAPP transgenic mouse, which overexpresses mutant human APP (V717F) [7]. Active immunization with the $A \beta_{1-42}$ peptide drastically reduced the amyloid burden in the cortex and in the hippocampus. Subsequently, the effectiveness of passive A $\beta$ immunotherapy, i.e., administering A $\beta$-directed antibodies, was shown in the same mouse model [8]. Once clinical trials with animal models were successfully achieved, clinical trials with humans actively vaccinated with $\mathrm{A} \beta_{1-42}$ were developed [9], however, the so-called AN-1792 clinical trial was halted because meningoencephalitis complications arose [10]. Although the treatment was stopped, those patients that were initially immunized continued to be monitored and a significant slowdown of the expected cognitive decline was reported [11]. At this time, and after several studies to prevent undesirable effects, the most advanced clinical trials are those for the ACC-001 vaccine, a derivative of the A $\beta$ peptide, and antibody AAB-001, or Bapineuzumab, a murine mAb against the N-terminal 1-5 residues of the $A \beta$ peptide (mAb-h3D6) which is specific for $A \beta$ oligomers [12-14].

Apart from the aforementioned meningoencephalitis, one of the side-effects of the administration of full $\mathrm{mAb}$ is the exacerbation of Cerebral Amyloid Angiopathy (CAA) [15]. Passive immunization with single-chain variable fragments ( $\mathrm{scFv}$ ), that is, antibodies devoid of $\mathrm{Fc}$, is an attractive therapeutic strategy since they do not activate microglia, do not produce cerebral hemorrhage, and have been demonstrated to be as potent and specific as the parent mAb [16-18]. Nevertheless, the yield after recombinant expression and purification of $\mathrm{scFv}$ fragments remains, in general, too low, especially when the isolated (non-tagged) molecule is intended [19]. Production of scFv variants is usually performed in phage-display systems $[16,17]$ or in the periplasm of Escherichia coli $[18,20]$, and just a few cases of soluble expression of tagged-scFvs within the cytoplasm of Origami 2 (DE3), a defective strain for the two main redox-pathways in E. coli, are reported [19,21].

In this work the sequence of the mAb-h3D6.v2 has been used to construct a synthetic gene consisting of the variable domain of the heavy-chain $\left(\mathrm{V}_{\mathrm{H}}\right)$ and the variable domain of the light-chain $\left(\mathrm{V}_{\mathrm{L}}\right)$ fused by a $\left(\mathrm{Gly}_{4} \mathrm{Ser}\right)_{3}$ linker (scFv-h3D6). Expression of thioredoxin- and NusA-tagged precursors was performed in E. coli Origami 2 (DE3), and the tags were afterwards efficiently removed by TEV proteolysis. Demonstration of the effectiveness of scFv-h3D6 on reversing A $\beta$-induced toxicity was assessed in the SH-SY5Y neuroblastoma cell-line. The subsequent description of the conformational landscape of scFv-h3D6 upon temperature perturbation permitted our group to gain insight into the molecular mechanisms behind its capability to capture $A \beta_{1-42}$ oligomers. Heat treatment of scFv-h3D6 initiates an aggregation pathway characterized by a $\beta$-rich intermediate state which aggregates in the form of worm-like (WL) fibrils. These fibrils are different from the amyloid fibrils formed by the A $\beta$ peptide, especially in terms of the toxicity of their oligomeric precursors. In addition, the formation of WL fibrils by scFv-h3D6 is kinetically and thermodynamically favored upon binding $\mathrm{A} \beta_{1-42}$ oligomers, explaining how scFv-h3D6 withdraws $A \beta_{1-42}$ oligomers from the amyloid pathway and, consistently, how it prevents cytotoxicity. 


\section{EXPERIMENTAL}

Large-scale expression and purification of $s c F v-h 3 D 6$. For large-scale production, the intracellular expression in pETtrx-1a allowed for the purification of the soluble and the insoluble fractions. Induction with $0.5 \mathrm{mM}$ IPTG was performed at OD 0.7 and was then incubated in the shaker at $20^{\circ} \mathrm{C}$ for $15 \mathrm{~h}$. The cellular pellet was then washed three times with cold PBS (pH 7.4) and resuspended in $\mathrm{Ni}^{2+}$-binding buffer $(20 \mathrm{mM}$ sodium phosphate, $0.5 \mathrm{M} \mathrm{NaCl}, 0.5 \mathrm{mM}$ EDTA, $\mathrm{pH}$ 7.4) containing a cocktail of protease inhibitors $(1 \mu \mathrm{g} / \mathrm{mL}$ leupeptine, $1 \mu \mathrm{g} / \mathrm{mL}$ benzamidine, $1 \mu \mathrm{g} / \mathrm{mL}$ BPTI, and $1 \mathrm{mM}$ PMSF). After two freeze-thaw cycles, the sample was sonicated for 5 cycles of $45 \mathrm{~s}$, at $50 \%$ duty cycle and output 9 (Sonifier 450, Banson). The soluble and the insoluble fractions were fractionated at $43,700 \mathrm{~g}$. The soluble fraction, containing a 40.6-KDa precursor ( His $_{6}$-thioredoxin-TEV target-scFv), was purified by $5-\mathrm{mL}$ Histrap HP columns (GE Healthcare). The presence of $0.5 \mathrm{mM}$ EDTA was necessary to preclude undesirable proteolysis within the time-course of the IMAC chromatography. This precursor was also obtained by solubilizing the insoluble fraction in denaturing buffer $(100 \mathrm{mM}$ Tris- $\mathrm{HCl}, 10 \mathrm{mM}$ reduced glutathione, $\mathrm{pH} 8.5$, urea $8 \mathrm{M})$ and refolding by dilution (1:10) in cold refolding buffer $(100 \mathrm{mM}$ tris, $100 \mathrm{mM}$ L-Arg, $0.15 \mathrm{mM}$ oxidized glutathione, $\mathrm{pH} 8.5)$ for $48 \mathrm{~h}$. The precursor was proteolized at $30^{\circ} \mathrm{C}$ with TEV protease for $4 \mathrm{~h}$ at a precursor:protease ratio of $50: 1$ (w:w) in $20 \mathrm{mM}$ tris- $\mathrm{HCl}, 100 \mathrm{mM} \mathrm{NaCl}, 0.5 \mathrm{mM}$ EDTA, GSSG $0.3 \mathrm{mM}$, GSH $3 \mathrm{mM}, \mathrm{pH} 8.3$ [22]. TEV protease was recombinantly obtained as described [23]. The scFv was fractionated from the initial fusion by binding the His-tagged proteins (Trx, and TEV protease) to 1-mL Histrap HP columns (GE Healthcare). Finally, a superdex-75 gel-filtration chromatography (Hiload 26/60, GE Healthcare) in PBS (pH 7.4) at a flow rate of $2 \mathrm{ml} / \mathrm{min}$ was used to both completely purify and to assess the degree of dimerization of the isolated $\mathrm{scFv}-\mathrm{h} 3 \mathrm{D} 6$.

Because the yield with the fusion to thioredoxin was not very high, and also because some undesirable proteolysis within the course of the initial IMAC chromatography was observed, an 83.4-KDa precursor containing NusA ( $\mathrm{His}_{6}-\mathrm{NusA}-\mathrm{TEV}$ target-scFv) was expressed. The protocol for purifying from the soluble fraction was similar to that described for the thioredoxin fusion, with the only modification being that of the $\mathrm{Ni}^{2+}$-binding buffer $(20 \mathrm{mM}$ Tris-HCl, $0.5 \mathrm{M} \mathrm{NaCl}, \mathrm{pH} \mathrm{8.0})$.

Finally, and in order to perform functional assays (i.e., MTT), lipopolysaccharides (LPS) were removed from the protein by using Detoxi-Gel Endotoxin Removing columns (Thermo Scientific). LPS are the major endotoxins of gram-negative bacteria, and they could elicit a cellular response (up to $300 \%$ of viability in the MTT assay was detected; data not shown).

The buffer was changed to PBS by PD-10 (GE Healthcare) and protein aliquots were stored at $-20^{\circ} \mathrm{C}$ until their use. The molecular mass of the different batches of purified protein was confirmed by MALDI-TOF spectrometry, and the protein concentration was determined from its absorbance at $280 \mathrm{~nm}$ using an extinction coefficient of $1.5 \mathrm{AU} \mathrm{cm}^{-1}$ for a $1 \mathrm{mg} / \mathrm{mL}$ native scFv-h3D6 solution, as determined by the method of Gill and von Gippel [24].

Secondary structure determination: $C D$ and FTIR- Protein secondary structure was monitored at different temperatures by far-UV CD-spectroscopy from $260 \mathrm{~nm}-190 \mathrm{~nm}$ in a Jasco J-715 spectrophotopolarimeter. The protein concentration was $20 \mu \mathrm{M}$, and 20 scans were recorded in cuvettes of a $0.2-\mathrm{cm}$ pathlength at $50 \mathrm{~nm} \mathrm{~min} \mathrm{~m}^{-1}$ (response $2 \mathrm{~s}$ ).

ScFv-h3D6 at $100 \mu \mathrm{M}(2.6 \mathrm{mg} / \mathrm{mL})$ was dialyzed at $4^{\circ} \mathrm{C}$ against deuterated-PBS using 15,000 MWCO MINI Dialysis Units (G-Biosciences) for FTIR analysis, and the completeness of the $\mathrm{H} \rightarrow \mathrm{D}$ exchange was monitored by the disappearance of the amide II band $\left(1545 \mathrm{~cm}^{-1}\right)$. Spectra were acquired at $25^{\circ} \mathrm{C}, 37^{\circ} \mathrm{C}$, and $60^{\circ} \mathrm{C}$ in a Variant Resolutions Pro spectrometer using excavated cells with a $50-\mu \mathrm{m}$ path (Reflex Analytical Co.) and the series software licensed under OMNIC (Thermo; Madison, Wi). Typically, 1000 spectra recorded at a scan rate of $95 \mathrm{~cm}^{-1} / \mathrm{min}$ were averaged, and the series obtained was corrected against a background, the buffer was subtracted, and a vapor-control spectrum was finally subtracted. Data treatment and band decomposition of the original amide I band have been described elsewhere [25]. Briefly, the number and position of the component bands are obtained by deconvolution and derivation [25]. Bandwidths are estimated from the derivatives, and bandshape is set to a Gaussian curve. The fitting is obtained by iteration in two steps: band positions are fixed in a first iteration and are free in the second. 
Thermal denaturation- Thermal denaturation was followed up by far-UV CD, Trp fluorescence and turbidity of $20-\mu \mathrm{M}$ samples (Trp fluorescence was also assayed at $2 \mu \mathrm{M}$ ). Experiments were carried out from $25^{\circ} \mathrm{C}-90^{\circ} \mathrm{C}$, at a rate of $60^{\circ} \mathrm{C} / \mathrm{h}$, by following the ellipticity at $218 \mathrm{~nm}$, Trp fluorescence at $338 \mathrm{~nm}$ (excitation 290nm, slits set at 5) and optical absorbance at $350 \mathrm{~nm}$. CD and Trp-fluorescenceemission spectra were recorded initially, at $90^{\circ} \mathrm{C}$, and again after cooling down the samples to $25^{\circ} \mathrm{C}$.

Limited protease digestion studies- To characterize the intermediate state present in the heat-induced aggregation pathway, limited thermolysin digestion was performed at $60^{\circ} \mathrm{C}$ for $2 \mathrm{~h}$ in $20 \mathrm{mM}$ Tris- $\mathrm{HCl}$, $10 \mathrm{mM} \mathrm{CaCl}$ ( $\mathrm{pH} 7.8$ ), and time-course aliquots were stopped with SDS-loading buffer [26]. A 1$\mathrm{mg} / \mathrm{mL}$ sample of scFv-h3D6 was pre-incubated at $60^{\circ} \mathrm{C}$ for $10 \mathrm{~min}$ and a ratio of thermolysin to scFv of 1:400 (w:w) was used. Thermolysin hydrolyzes peptide bonds on the N-terminal side of Val, Leu, Ile and Phe residues [27].

Preparation of the A $\beta$ peptide and aggregation- $\mathrm{An} A \beta_{1-42}$ synthetic lyophilized peptide, purified with $\mathrm{HCl}$ as the counter-ion (Caslo Laboratories ApS; Denmark), was dissolved at $200 \mu \mathrm{M}$ in 1,1,1,3,3,3hexafluoro-2-isopropanol (HFIP), a pre-treatment that breaks down $\beta$-sheet structures and disrupts hydrophobic forces, leading to monodispersed peptide preparations [28]. Aliquots of $150 \mu \mathrm{L}$ were prepared, and HFIP was removed by drying in vacuum in a SpeedVac (Savant instruments), and the resulting peptide film was then stored at $-80^{\circ} \mathrm{C}$ until its use. The peptide film was dissolved with $6 \mu \mathrm{L}$ of dry dimethyl sulfoxide (DMSO) (5 mM peptide) and subsequently taken to $300 \mu \mathrm{L}$ with PBS (100 $\mu \mathrm{M}$ peptide). Oligomerization was induced by incubation at $37^{\circ} \mathrm{C}$ for different periods of time, whereas fibrillation was induced by heating the samples at $90^{\circ} \mathrm{C}$ for $5 \mathrm{~min}$.

Because of the method of preparation of the A $\beta$ peptide, $2 \%$ DMSO (v:v) remained in the initial solution, and all of the samples to assess the effect of scFv-h3D6 on A $\beta$-peptide aggregation and cytotoxicity, including control samples, contained the same percentage of DMSO during incubation. It is worth noting that a 10 -fold dilution was performed after incubation when analyzing cytotoxicity, ThT and ANS binding, and TEM (see below), so $0.2 \%$ DMSO (v:v) remained in the final samples. Additionally, we have found that $\%$ DMSO does not affect the far-UV CD-spectrum of scFv-h3D6 (see Supplementary Figure 1).

Cytotoxicity assays- The SH-SY5Y human neuroblastoma cell-line was grown in $5 \% \mathrm{CO}_{2}$ at $37^{\circ} \mathrm{C}$ in serum-supplemented medium. The medium contained 50\% minimal essential medium (MEM) (Invitrogen; USA), 50\% Ham's modification of F-12 (Invitrogen; USA), and was supplemented with $10 \%$ fetal bovine serum (Sigma; USA), $1 \%$ MEM non-essential amino acids (Gibco; USA) and a 1\% mix of antibiotics: penicillin, streptomycin and anti-fungal amphotericin (Gibco; USA). Cells were plated in 96-well tissue-culture-treated plates (Corning; USA) at $3 \times 10^{4}$ cells/well in $100 \mu \mathrm{l}$ of medium, and incubated for $24 \mathrm{~h}$ to allow for the attachment to the bottom of the wells. Medium was removed by aspiration and replaced with $100 \mu \mathrm{l}$ of serum-free medium. We first determined the optimal concentration of the $A \beta_{1-42}$ peptide to generate maximum cell toxicity by assaying samples ranging from $0 \mu \mathrm{M}$ to $200 \mu \mathrm{M}$ which were induced for oligomerization $\left(37^{\circ} \mathrm{C}, 3 \mathrm{~h}\right)$ before adding 10 $\mu \mathrm{L}$ to each well; cells were incubated with the peptide for $24 \mathrm{~h}$. To assess the effect of scFv-h3D6 on the recovery of $A \beta_{1-42}$-induced cell toxicity, samples of $100 \mu \mathrm{M} A \beta_{1-42}$ peptide with increasing concentrations of scFv-h3D6 $(0,1,10,50,100 \mu \mathrm{M})$, were treated and assayed similarly. The MTT assay was performed. The 3-[4,5-dimethylthiazol-2-yl]-2,5-diphenyl tetrazolium bromide (MTT) reagent was reconstituted in PBS to $5 \mathrm{mg} / \mathrm{ml}$. Ten $\mu \mathrm{l}$ of MTT labeling reagent were added to each well, and the plate was incubated at $37^{\circ} \mathrm{C}$ for $4 \mathrm{~h}$. After removal by aspiration, $100 \mu \mathrm{l}$ of solubilization solution (DMSO) was added to each well, and the plate was shaken for $10 \mathrm{~min}$ at room temperature. The absorbance of the samples was measured at $540 \mathrm{~nm}$ (absorbance at $620 \mathrm{~nm}$ was afterwards subtracted) in a Microplate Photometer (Packard Instrument Co.). Each condition consisted of six replicas per experiment, and four independent experiments were statistically analyzed for significance (Wilcoxon signed-rank test, SPSS) after standardizing the data using concentration 0 (buffer) as the reference. 
Transmission electron microscopy- One-hundred $\mu \mathrm{M} A \beta_{1-42}$ peptide, $100 \mu \mathrm{M}$ scFv-h3D6 and the combination of both molecules at the same concentration were induced for oligomerization $\left(37^{\circ} \mathrm{C}, 3 \mathrm{~h}\right.$ and $48 \mathrm{~h})$ and for amyloid fibril formation $\left(90^{\circ} \mathrm{C}, 5 \mathrm{~min}\right)$ and then analyzed. Incubation at $60^{\circ} \mathrm{C}$ for 10 min was also studied to obtain information about the heat-induced intermediate state (see Results). The samples were diluted 1/10 in PBS and quickly adsorbed onto glow-discharged carbon-coated grids. The material was stained using the method of uranyl acetate described elsewhere [29], and the samples were visualized with a Hitachi H-7000 microscope.

ThT and ANS fluorescence-based aggregation assays- ThT and ANS fluorescence were used to quantify the aggregation extent of the samples visualized by TEM (preceding paragraph). A $10-\mu \mathrm{L}$ sample was added to $90 \mu \mathrm{L}$ of a $27.78-\mu \mathrm{M}$ ThT solution (final concentration $25 \mu \mathrm{M}$ ) or of a $56-\mu \mathrm{M}$ ANS solution (final concentration $50 \mu \mathrm{M}$ ), and monitored at $25^{\circ} \mathrm{C}$. The excitation wavelengths were $450 \mathrm{~nm}$ for ThT (emission $470 \mathrm{~nm}-530 \mathrm{~nm}$ ) and $388 \mathrm{~nm}$ for ANS (emission $400 \mathrm{~nm}-600 \mathrm{~nm}$ ); both slits were set to 10 , and 10 spectra were averaged for each measurement. The intensities were quantified at $482 \mathrm{~nm}$ for ThT and at $470 \mathrm{~nm}$ for ANS. Each condition consisted of three replicas per experiment, and six independent experiments were averaged after standardizing the data using time 0 as the reference. Kinetics of ThT and ANS binding upon thermal denaturation (heating rate of $60^{\circ} \mathrm{C} / \mathrm{h}$ ) were followed at $482 \mathrm{~nm}$ and $470 \mathrm{~nm}$, respectively.

\section{RESULTS}

Expression and purification of $s c F v-h 3 D 6$. A 750-pb NcoI-NotI fragment coding for the sequence of the $\mathrm{V}_{\mathrm{H}}$ domain of the humanized mAb h3D6.v2, a (Gly $\left.{ }_{4} \mathrm{Ser}\right)_{3}$ linker, and the sequence of the $\mathrm{V}_{\mathrm{L}}$ domain of the same antibody, was designed and synthesized (GenScript Co.). The fragment was subcloned into different $\mathrm{pETM}$-derived vectors containing a His-tag, a signal peptide (DsbA, DsbC, PelB) or a protein tag (MBP, Ztag, GB1, GST, thioredoxin, NusA), as well as the target sequence for the TEV protease. The E. coli BL21 (DE3) strain was used to secrete the recombinant protein to the periplasmic space, whereas the Origami 2 (DE3) strain was used to propitiate correct folding in the cytoplasm. None of the signal peptides gave a high yield of recombinant protein, in consonance with published data for other scFv sequences secreted to periplasmic space $[18,30]$. Origami 2 (DE3), a strain carrying mutations in the major intracellular disulphide-bond reduction systems -the glutathione/glutaredoxin and thioredoxin pathways-, allowed for correct folding in the cytoplasm of this disulphide-containing protein (see following section). The protein was N-tagged expressed (His $6_{6^{-}}$ thioredoxin-TEV target-scFv; 40.6 KDa) and digestion with the TEV protease released the isolated scFv-h3D6 (26.4 KDa). Digestion of the precursory fusion obtained from the soluble fraction was quite efficient, but it was revealed to be rather inefficient when using the refolded one (data not shown). At the end of the process, the yield of purified scFv-h3D6 from the soluble fraction was approximately $1 \mathrm{mg} / \mathrm{L}$, whereas that obtained by refolding from inclusion bodies was approximately 4 $\mathrm{mg} / \mathrm{L}$.

Nevertheless, some undesirable proteolysis was observed within the time-course of the initial IMAC chromatography, and $0.5 \mathrm{mM}$ of EDTA was mandatory in the binding buffer to preclude the generation of a scFv with two extra residues in its N-terminus (as determined by blotting and subsequent $\mathrm{N}$-terminal sequencing). The proteolysis during IMAC might be indicative of an improper packing between the thioredoxin domain and the $\mathrm{scFv}$, which could permit some E. coli metalloprotease to bind. For this reason, together with the aim of increasing the final yield, the scFvh3D6 was expressed as a fusion to NusA (His ${ }_{6}$-NusA-TEV target-scFv; $83.4 \mathrm{KDa}$ ), and the precursor obtained did not show any undesirable proteolysis. Additionally, the high level of expression in the soluble form makes the refolding from the insoluble fraction unnecessary and permits a complete cleavage from the precursory form by the TEV protease. The final yield obtained for the isolated scFv-h3D6 was $7 \mathrm{mg} / \mathrm{L}$.

The tendency is known for scFv molecules to dimerize, presumably by domain swapping [31]. These dimers appear to be kinetically trapped species produced during recombinant expression. The final step of purification consisted of a superdex-75 gel filtration in PBS and rendered around $15 \%$ of dimerized scFv. The purified monomeric form of scFv-h3D6 was analyzed at the highest 
concentration used in this work $(200 \mu \mathrm{M})$ by the same method and proved to be $100 \%$ monomeric (data not shown).

Secondary structure of $s c F v-h 3 D 6$. Before performing functional assays, the folding of scFv-h3D6 was characterized at different temperatures by circular dicroism (CD) and infrared spectroscopy (FTIR). Figure 1A shows two ellipticity minima $(218 \mathrm{~nm}$ and $230 \mathrm{~nm})$, an ellipticity maximum $(200 \mathrm{~nm})$ and a positive shoulder $(237 \mathrm{~nm})$ in the CD spectrum of the native state recorded at $25^{\circ} \mathrm{C}$. The spectrum recorded at $37^{\circ} \mathrm{C}$ is identical (data not shown). The ellipticity minimum at $218 \mathrm{~nm}$, together with the ellipticity maximum at $200 \mathrm{~nm}$, shows the typical Ig $\beta$-sheet secondary structure. The CD contributions from the aromatic and/or cystinyl side-chains can interfere in the far-UV CD spectra and could explain the second ellipticity minimum at $230 \mathrm{~nm}$ and the positive shoulder at $237 \mathrm{~nm}$ [32]. This particular shape of the spectra is lost at $60^{\circ} \mathrm{C}$ (Figure 1A); indeed, the spectra recorded at $60^{\circ} \mathrm{C}$ and at $90^{\circ} \mathrm{C}$ show a canonical $\beta$-sheet conformation (a single ellipticity minimum at $215 \mathrm{~nm}$ ) that is maintained after returning to $25^{\circ} \mathrm{C}$ (data not shown), indicating that the thermal denaturation of scFvh3D6 follows an irreversible process.

Because the particular shape of the initial CD spectrum actually precludes deconvolution, analysis by FTIR was performed at different temperatures (Figure 1B-D, Table 1). Band decomposition of the amide I spectrum at $25^{\circ} \mathrm{C}$ generates three main bands located at $1681 \mathrm{~cm}^{-1}, 1660 \mathrm{~cm}^{-1}$, and $1636 \mathrm{~cm}^{-1}$, and a minor band located at $1612 \mathrm{~cm}^{-1}$ (Figure 1B). The low- and high-frequency components of the antiparallel $\beta$-sheet, characteristic of an Ig fold, are located at $1636 \mathrm{~cm}^{-1}$ and $1681 \mathrm{~cm}^{-1}$, respectively, and its $\beta$-turns/loops are located at $1660 \mathrm{~cm}^{-1}[33,34]$. At $37^{\circ} \mathrm{C}$ the spectrum is very similar (Figure 1C) although the component for turns/loops slightly increases (Table 1). However, band decomposition of the spectrum acquired at $60^{\circ} \mathrm{C}$ generates four additional bands located at $1671 \mathrm{~cm}^{-1}$, $1653 \mathrm{~cm}^{-1}, 1644 \mathrm{~cm}^{-1}$ and $1626 \mathrm{~cm}^{-1}$ (Figure 1D). The $1671 \mathrm{~cm}^{-1}$ band is assigned to $\beta$-turns/loops in the bibliography, as is the band at $1660 \mathrm{~cm}^{-1}$ [33]. The band at $1653 \mathrm{~cm}^{-1}$ corresponds to $\alpha$-helices, the $1644 \mathrm{~cm}^{-1}$ to random coil, and the $1626 \mathrm{~cm}^{-1}$ to worm-like (WL) fibrils [35]. Although also accompanied by an increase of the $1615 \mathrm{~cm}^{-1}$ band, assigned to amyloid fibrils [36], the different $\beta$ conformation detectable by far-UV CD upon heating scFv-h3D6 mainly corresponds to the presence of WL fibrils (Table 1) (see below). Amyloid and WL fibrils populate different aggregation pathways: amyloid fibrils are straight and long, and form following a nucleated-dependent kinetics whereas WL fibrils are curved and short, and form following a non-nucleated-dependent kinetics [37].

Thermal denaturation of $s c F v$ - $h 3 D 6$. To delve into the conformational transition from the native state to that observed at $60^{\circ} \mathrm{C}$, thermal denaturation was followed up by $\mathrm{CD}, \operatorname{Trp}$ fluorescence, and turbidity (Figure 1E-F). Ellipticity at $218 \mathrm{~nm}$ decreases with the temperature starting at $45^{\circ} \mathrm{C}$, such that the fold enriches its $\beta$-sheet content (Figure 1E). At $60^{\circ} \mathrm{C}$, however, there is a transition that leads to the loss of part of this newly acquired $\beta$-content and the stabilization of the signal at above $65^{\circ} \mathrm{C}$. The fact that the $\beta$-content initially increases, without previously suffering from an evident unfolding, shows a direct rearrangement of the native $\beta$-sheets. This rearrangement leads to partial aggregation, as also seen de visu, and subsequent partial loss of the signal. Turbidity also corroborates that thermal denaturation leads to aggregation (Figure $1 \mathrm{~F}$ ). In consonance, the $\mathrm{CD}$ spectrum at $60^{\circ} \mathrm{C}$ was clearly different from the initial spectrum (Figure 1A), and thermal denaturation was revealed as not being reversible. This conformational reorganization leads to the appearance of an intermediate state, which is prone to aggregation and generates the WL-fibril FTIR-component described in the preceding paragraph.

Although it is known that intrinsic tryptophan fluorescence decreases with temperature and, in consequence, no quantification upon varying the temperature can be made, thermal denaturation followed by $\operatorname{Trp}$ fluorescence has been used to determine the effect of protein concentration in the aggregation process (Figure $1 \mathrm{~F}$ ). When comparing the thermal denaturation at $2-\mu \mathrm{M}$ and $20-\mu \mathrm{M}$ protein concentrations, a transition at around $60^{\circ} \mathrm{C}$ is observed in both cases. Although the transition region is sharper at the higher concentration, the slopes before and after this point remained unaffected, which implies that the aggregation of scFv-h3D6 follows a non-nucleated kinetics, as has previously been reported as being a main feature of WL fibrils [37]. 
In order to characterize the intermediate state in the aggregation pathway, limited proteolysis with thermolysin was performed at $60^{\circ} \mathrm{C}$ and analyzed by SDS-PAGE (see Supplementary Figure 2). No apparent band was accumulated during the time-course of the digestion, and after $2 \mathrm{~h}$ the scFv-h3D6 was completely proteolyzed. This indicates a conformation where both domains are equally susceptible to digestion.

Once we learned that the scFv-h3D6 is properly folded at temperatures below $60^{\circ} \mathrm{C}$, we were ready to test its effect on the toxicity of the $A \beta$ peptide in physiological conditions.

Prevention of $A \beta_{1-42}$ toxicity by $s c F v-h 3 D 6$. We first determined the optimal concentration of the $A \beta_{1-}$ 42 peptide to generate maximum cell toxicity in the human SH-SY5Y neuroblastoma cell-line, as determined by the MTT method. Figure $2 \mathrm{~A}$ shows $10 \mu \mathrm{M}$ and $20 \mu \mathrm{M}$ of the $\mathrm{A} \beta_{1-42}$ peptide as the most effective concentrations in the culture to reduce viability. Although, at first glance, the fact that 20 $\mu \mathrm{M} \mathrm{A} \beta_{1-42}$ is not more toxic than $10 \mu \mathrm{M}$ is surprising, it makes sense that at higher concentrations the aggregation pathway is shifted towards the formation of amyloid fibrils instead of towards the formation of oligomeric-cytotoxic species because amyloid fibrils form following a nucleateddependent kinetics. Since we are interested in reversing the toxicity of the $A \beta$ oligomers, $10 \mu \mathrm{M}$ of the $A \beta_{1-42}$ peptide in the MTT-assay shown in Figure $2 B$ has been used. Samples of $A \beta_{1-42}$ with different concentrations of scFv-h3D6 were induced for aggregation by incubation at $37^{\circ} \mathrm{C}$ for $3 \mathrm{~h}$. The treatment with $10 \mu \mathrm{M} \mathrm{A} \beta_{1-42}$ reduced cell viability to $60 \%, 10 \mu \mathrm{M}$ scFv-h3D6 alone had no effect, and the combination of both molecules recovered cell viability in a dose-dependent manner. A ratio of 2:1 $\left(10 \mu \mathrm{M} \mathrm{A} \beta_{1-42}: 5 \mu \mathrm{M} \mathrm{scFv}-\mathrm{h} 3 \mathrm{D} 6\right)$ was enough to observe a significant effect, with the equimolar ratio being the one that almost completely abolished the toxicity induced by the $\mathrm{A} \beta_{1-42}$ peptide.

Because of the therapeutic potential of scFv-h3D6, it is encouraging to gain insight into the conformational changes underlying the prevention of $A \beta$ toxicity by this antibody fragment. Given that the $\mathrm{A} \beta$ peptide follows the amyloid fibril pathway and that the scFv-h3D6 follows the WL fibril pathway (see preceding subsection), it becomes necessary to study these misfolding pathways separately to further study what occurs when both molecules are combined.

Misfolding of the $A \beta_{1-42}$ peptide. Since mAb-h3D6 preferentially recognizes A $\beta$ oligomers [12-14], which are the precursors of amyloid fibrils and the cytotoxic species, we purposely used mild conditions (PBS, $3 \mathrm{~h}$ at $37^{\circ} \mathrm{C}$ ) to aggregate the $\mathrm{A} \beta_{1-42}$ peptide before adding it to the cell cultures. To demonstrate that in these conditions oligomers are actually formed, electron transmission microscopy (TEM) was performed (Figure 3A). Oligomers are visualized just upon dilution of the A $\beta$-peptide film (see Experimental Section) and remain after incubation for different periods at $37^{\circ} \mathrm{C}$, without the occurrence of amyloid fibrils. This observation does not mean we are out of the amyloid fibril pathway because heat treatment $\left(60^{\circ} \mathrm{C}\right.$ and $\left.90^{\circ} \mathrm{C}\right)$ induces the formation of amyloid fibrils.

The different temperature treatments performed for TEM visualization have also been performed before quantifying ThT and ANS binding at $25^{\circ} \mathrm{C}$ (Figure 4A-B). ThT is considered to be a specific dye for amyloid fibrils [38]; whereas ANS has been extensively used as a probe of hydrophobic binding sites in proteins [39]. In the conditions used in this work, the $A \beta_{1-42}$ peptide initially binds some ThT, and treatment at $90^{\circ} \mathrm{C}$ increases the fluorescence signal two-fold (Figure 4A), whereas a very low level of ANS binding is detected, even upon heating (Figure 4B). This indicates that we are, effectively, on the amyloid pathway.

Misfolding of $s c F v-h 3 D 6$. As mentioned before, heat treatment of scFv-h3D6 initiates an aggregation pathway characterized by a $\beta$-rich intermediate state which aggregates in the form of worm-like (WL) fibrils. Unexpectedly, these WL fibrils were not visualized by TEM when assaying scFv-h3D6 alone, instead, oligomers appeared in all of the tested conditions (Figure 3B). It is important to note that these sets of experiments, as well as all of the experiments to assay the effect of scFv-h3D6 in A $\beta$ peptide cytotoxicity and aggregation, contained $2 \%$ DMSO during incubation $(0.2 \%$ in the final samples) in order to properly be compared to those in the presence of the A $\beta$ peptide, which inevitably contained these DMSO traces (see Experimental section). As expected, when DMSO is not present, WL fibril formation by the isolated scFv-h3D6 is initiated upon incubation at $60^{\circ} \mathrm{C}$, and this becomes more evident upon treatment at $90^{\circ} \mathrm{C}$ (Figure 3C). This is in consonance with the FTIR 
analysis previously shown, where a characteristic band for WL fibrils appeared at $60^{\circ} \mathrm{C}$ (Figure $1 \mathrm{D}$, Table 1).

ScFv-h3D6 alone does not bind ThT, and temperature induces just some binding, especially at the temperature where the heat-induced intermediate state is present (Figure 4A). ANS is bound to scFvh3D6 in all of the conditions, although also preferentially at the temperature where the heat-induced intermediate state is present (Figure 4B). The behavior is similar when no traces of DMSO are present (result not shown), revealing that neither ThT nor ANS are capable of distinguishing between the oligomers and the WL fibrils formed by scFv-h3D6.

In order to confirm the relevance of the heat-induced intermediate state in the aggregation pathway of scFv-h3D6, the ThT and ANS binding kinetics upon heating were assayed without stirring (Figure $4 \mathrm{C}-\mathrm{D})$. Effectively, at $60^{\circ} \mathrm{C}$ both dyes are bound to the intermediate state, and at higher temperatures the signal is lost because insoluble aggregation occurs.

What occurs with misfolding pathways when the $A \beta_{1-42}$ peptide and $s c F v-h 3 D 6$ are combined? The addition of an equimolar ratio of scFv-h3D6 to the $A \beta_{1-42}$ peptide prevented the formation of $A \beta$ oligomers and, in its place, initiated the formation of WL fibrils immediately after mixing (Figure $3 \mathrm{D})$. These WL fibrils were present in the samples used for the cytotoxicity assays $\left(3 \mathrm{~h}\right.$ at $\left.37^{\circ} \mathrm{C}\right)-$ where the toxicity of $\mathrm{A} \beta$ oligomers was prevented (Figure 2B)- and at a longer period of incubation $\left(48 \mathrm{~h}\right.$ at $37^{\circ} \mathrm{C}$ ) become more evident. When the WL fibrils of the $\mathrm{A} \beta_{1-42} \mathrm{scFv}-\mathrm{h} 3 \mathrm{D} 6 \mathrm{complex}$ are heated at $60^{\circ} \mathrm{C}$-the temperature where the heat-induced intermediate of scFv-h3D6 is observed- they begin to disassemble, and at $90^{\circ} \mathrm{C}$ both amyloid fibrils and oligomers appear. Taking into account that WL fibrils are kinetically trapped species, the temperature has depopulated this state, allowing the actual amyloid-fibril pathway by the $\mathrm{A} \beta_{1-42}$ peptide to proceed.

In contrast to the behavior of the scFv-h3D6 alone, when mixing $\mathrm{A} \beta_{1-42}: \mathrm{scFv}-\mathrm{h} 3 \mathrm{D} 6$ the binding of ThT and ANS is apparent from time $0 \mathrm{~h}$ and becomes more evident upon heating (especially at $90^{\circ} \mathrm{C}$ ) (Figure 4A-B). This agrees with the presence of WL fibrils, which are known to bind both dyes $[37,40]$, before heating and the presence of amyloid fibrils and oligomers upon heating.

Hence, it appears that, albeit the formation of WL fibrils is an intrinsic property of the scFv-h3D6, those made by the $\mathrm{A} \beta_{1-42}: \mathrm{scFv}-\mathrm{h} 3 \mathrm{D} 6$ complex are more stable than those made by the isolated scFvh3D6 because they occur without the requirement of heat treatment and even occur in the presence of DMSO traces.

\section{DISCUSSION}

Herein the production and conformational characterization of a $\mathrm{scFv}$ designed from the sequence of a $\mathrm{mAb}$ of therapeutic interest for Alzheimer's disease is described. Passive immunization with $\mathrm{scFv}$ is an appealing therapeutic strategy since it does not produce the undesirable side-effects of complete antibody administration while maintaining the avidity of the parent mAb [16-18].

Expression of $s c F v-h 3 D 6$ and chaperone activity. The effective recombinant production of $\mathrm{scFv}$ fragments remains a challenging matter mainly because of the difficulty of properly folding both cystinyl-containing domains. In this work, acceptable yields have been obtained from both the soluble and the insoluble-refolded fractions by expressing, in the cytoplasm of E. coli Origami 2 (DE3), a Trx-tagged scFv that afterwards was released by TEV proteolysis. Thioredoxin has also been useful in producing other functional scFvs, and its capability has been related to its chaperone activity rather than to its disulphide-isomerase activity [21]. A fusion to NusA, a protein known to mediate termination of transcription [41] and to display chaperone activity [42], was also tried. To our knowledge, the highest yield for a soluble scFv in the cytoplasm of Origami 2 (DE3) has been obtained by expressing a NusA-tagged precursor $(3 \mathrm{mg} / \mathrm{L})$ [19]. In this work, the fusion to this chaperone allowed us to obtain a soluble precursor that generated, after TEV protease digestion, a yield of $7 \mathrm{mg} / \mathrm{L}$ of scFv-h3D6. Thus, it is likely that, in order to properly fold cystinyl-containing domains in the cytoplasm of Origami 2 (DE3), it is advisable to improve chaperone activity. 
Folding landscape of scFv-h3D6 upon temperature perturbation. ScFv-h3D6 shows the typical secondary structure of an Ig fold, with around $60 \%$ of antiparallel $\beta$-sheet and $30 \%$ of loops/turns components, as determined by FTIR. The CD spectrum of the native protein is affected by contributions from the aromatic and/or cystinyl side-chains within the far-UV [32], featuring a second ellipticity minimum at $230 \mathrm{~nm}$ and a positive shoulder at $237 \mathrm{~nm}$. Although other scFv molecules in the literature show ordinary $\beta$-sheet spectra [43-46], the second ellipticity minimum presented herein is very similar to that which recently has been described at $235 \mathrm{~nm}$ for a $\mathrm{V}_{\mathrm{L}}$ domain [47]. This ellipticity minimum was attributed to the interaction of the aromatic residues with the conserved Trp 35.

Thermal denaturation of scFv-h3D6 leads to aggregation, as seen by CD, Trp fluorescence, and turbidity. The $\mathrm{CD}$ spectrum in the mid-point of the transition $\left(60^{\circ} \mathrm{C}\right)$ shows the presence of an intermediate state with a conformation similar to that at $90^{\circ} \mathrm{C}$; this intermediate state is generated by direct reorganization of the native state, and no unfolding is required in order to enter the aggregation funnel. When submitted to thermolysin proteolysis, a defined pattern of digestion was not obtained, suggesting that both domains are equally susceptible to proteolysis. This $\beta$-rich intermediate state accumulates in a concentration-independent fashion, following a non-nucleation-dependent kinetics. In consonance, heat-induced aggregation of $\mathrm{scFv}-\mathrm{h} 3 \mathrm{D} 6$ leads to the formation of WL fibrils rather than to amyloid fibrils, as indicated by TEM. These WL fibrils are known to follow a nucleationindependent kinetics and to bind to ThT and ANS [37,40]. Additionally, the FTIR spectrum of these WL fibrils shows a band at $1626 \mathrm{~cm}^{-1}$, similar to the $1622 \mathrm{~cm}^{-1}$ band characteristic for the WL fibrils of $\beta 2$-microglobulin [35]. Despite the fact that both folds correspond to the same class (Ig fold), it has been demonstrated that other folds can also form WL fibrils (i.e., [48]).

The general aggregation tendency of scFv molecules upon thermal denaturation has already been reported in the literature [44,49], but the conformational nature of these aggregates is described for the first time in this work. Other similar folds that are known to aggregate in vivo do form amyloid fibrils, as is the case for the light-chains of immunoglobulins, especially of their isolated variable domains $\left(\mathrm{V}_{\mathrm{L}}\right)$ [47], and the above-mentioned $\beta 2$-microglobulin (a 99-residue, all $\beta$-sheet protein from the major histocompatibility class I complex) [40]. Acidic $\mathrm{pH}$ and high ionic strength are necessary to observe WL fibrils in vitro of $\beta 2$-microglobulin [37], whereas those presented in this work for the scFv-h3D6 alone are formed in a physiological buffer (PBS) after heat induction.

Effect of $s c F v-h 3 D 6$ on $A \beta_{1-42}$ peptide fibrillation and toxicity. Recent evidence suggests that therapeutic interventions that reduce $A \beta$ fibrils at the cost of augmenting non-fibrillar $A \beta$ assemblies, including $A \beta$ oligomers, could be harmful [50]. The mAb from which scFv-h3D6 is derived specifically recognizes $A \beta$ oligomers [12].

When samples induced for oligomerization were added to cell cultures, $10 \mu \mathrm{M} \mathrm{scFv}$ alone had no effect, $10 \mu \mathrm{M} \mathrm{A} \beta_{1-42}$ reduced cell viability to $60 \%$, and the previous addition of scFv-h3D6 to $10 \mu \mathrm{M}$ $\mathrm{A} \beta_{1-42}$ annulled the effect of the peptide on cell viability in a dose-dependent manner. In the conditions used in this work for the cytotoxicity assays, $A \beta_{1-42}$ oligomers are formed as visualized by TEM. The fact that WL fibrils are formed when mixing the $A \beta_{1-42}$ peptide and scFv-h3D6, without the requirement of the isolated $\mathrm{scFV}$ of incubation at $60^{\circ} \mathrm{C}$ and in the presence of DMSO, implies that these WL fibrils are both kinetically and thermodynamically favored when scFv-h3D6 traps $\mathrm{A} \beta_{1-42}$ oligomers. Upon heating, the WL state becomes depopulated by dissociation of the complex and, in turn, some amyloid fibrils and oligomers appear. This would imply that temperature drags the $\mathrm{A} \beta$ peptide out of the WL pathway and into the amyloid pathway, whereas the scFv-h3D6 remains in the WL pathway in the form of oligomers (Figure 5). As has been demonstrated, in the presence of DMSO traces, inherent to the presence of the $\mathrm{A} \beta$ peptide, the oligomers of scFv-h3D6 can not assemble into WL fibrils.

Apart from the details of the aggregation pathways, the most relevant conclusion of this work is that in native conditions- scFv-h3D6 inhibits A $\beta$-peptide amyloid fibril formation and cytotoxicity by dragging its oligomers towards the WL pathway. The description of the mechanism by which scFvh3D6 protects against $A \beta$-peptide toxicity opens a new way to hereafter improve its therapeutic potential. 
Acknowledgements: The authors acknowledge Prof. Luis Serrano and Dr. Jose C. Martínez for their critical comments on the manuscript and Dra. Alicia Roque for her FTIR technical assistance.

Funding: Instituto de Salud Carlos III [FIS-PI07-0148, FIS-PI10-00975], Fundación Mutua Madrileña [FMM-08], and Generalitat de Catalunya [SGR 2009-00761]. G.R-H is supported by a MAEC-AECI (Ministerio de Asuntos Exteriores, Spain) fellowship and M.M-A by a PIF (UAB) fellowship.

\section{REFERENCES}

1 Yankner, B. A., Dawes, L. R., Fisher, S., Villa-Komaroff, L., Oster-Granite, M. L. and Neve, R. L. (1989) Neurotoxicity of a fragment of the amyloid precursor associated with alzheimer's disease. Science. 245, 417-420

2 Lansbury, P. T. and Lashuel, H. A. (2006) A century-old debate on protein aggregation and neurodegeneration enters the clinic. Nature. 443, 774-779. doi:10.1038/nature05290

3 Dineley, K. T., Xia, X., Bui, D., Sweatt, J. D. and Zheng, H. (2002) Accelerated plaque accumulation, associative learning deficits, and up-regulation of alpha 7 nicotinic receptor protein in transgenic mice co-expressing mutant human presenilin 1 and amyloid precursor proteins. J. Biol. Chem. 277, 22768-22780. doi:10.1074/jbc.M200164200

4 McLean, C. A., Cherny, R. A., Fraser, F. W., Fuller, S. J., Smith, M. J., Beyreuther, K., Bush, A. I. and Masters, C. L. (1999) Soluble pool of abeta amyloid as a determinant of severity of neurodegeneration in alzheimer's disease. Ann. Neurol. 46, 860-866

5 Solomon, B. (2009) Immunotherapeutic strategies for alzheimer's disease treatment. ScientificWorldJournal. 9, 909-919. doi:10.1100/tsw.2009.99

6 Solomon, B., Koppel, R., Frankel, D. and Hanan-Aharon, E. (1997) Disaggregation of alzheimer beta-amyloid by site-directed mAb. Proc. Natl. Acad. Sci. U. S. A. 94, 4109-4112

7 Schenk, D., Barbour, R., Dunn, W., Gordon, G., Grajeda, H., Guido, T., Hu, K., Huang, J., Johnson-Wood, K., Khan, K., Kholodenko, D., Lee, M., Liao, Z., Lieberburg, I., Motter, R., Mutter, L., Soriano, F., Shopp, G., Vasquez, N., Vandevert, C., Walker, S., Wogulis, M., Yednock, T., Games, D. and Seubert, P. (1999) Immunization with amyloid-beta attenuates alzheimer-disease-like pathology in the PDAPP mouse. Nature. 400, 173-177. doi:10.1038/22124

8 Bard, F., Cannon, C., Barbour, R., Burke, R. L., Games, D., Grajeda, H., Guido, T., Hu, K., Huang, J., Johnson-Wood, K., Khan, K., Kholodenko, D., Lee, M., Lieberburg, I., Motter, R., Nguyen, M., Soriano, F., Vasquez, N., Weiss, K., Welch, B., Seubert, P., Schenk, D. and Yednock, T. (2000) Peripherally administered antibodies against amyloid beta-peptide enter the central nervous system and reduce pathology in a mouse model of alzheimer disease. Nat. Med. 6, 916-919. doi: $10.1038 / 78682$

9 Schenk, D. (2002) Amyloid-beta immunotherapy for alzheimer's disease: The end of the beginning. Nat. Rev. Neurosci. 3, 824-828. doi:10.1038/nrn938

10 Nicoll, J. A., Wilkinson, D., Holmes, C., Steart, P., Markham, H. and Weller, R. O. (2003)

Neuropathology of human alzheimer disease after immunization with amyloid-beta peptide: A case report. Nat. Med. 9, 448-452. doi:10.1038/nm840

11 Hock, C., Konietzko, U., Streffer, J. R., Tracy, J., Signorell, A., Muller-Tillmanns, B., Lemke, U., Henke, K., Moritz, E., Garcia, E., Wollmer, M. A., Umbricht, D., de Quervain, D. J., Hofmann, M., Maddalena, A., Papassotiropoulos, A. and Nitsch, R. M. (2003) Antibodies against beta-amyloid slow cognitive decline in alzheimer's disease. Neuron. 38, 547-554

12 Jacobson, J. S. (2006) Antibodies specific for epitopes within amyloid $\beta$ (A $\beta$ ), for use in improving cognition. PCT Int. Appl. (2006), WO 2006066171 A1 20060622.

13 Wisniewski, T. and Konietzko, U. (2008) Amyloid-beta immunisation for alzheimer's disease. Lancet Neurol. 7, 805-811. doi:10.1016/S1474-4422(08)70170-4

14 Nitsch, R. M. and Hock, C. (2008) Targeting beta-amyloid pathology in alzheimer's disease with abeta immunotherapy. Neurotherapeutics. 5, 415-420. doi:10.1016/j.nurt.2008.05.013 
15 Pfeifer, M., Boncristiano, S., Bondolfi, L., Stalder, A., Deller, T., Staufenbiel, M., Mathews, P. M. and Jucker, M. (2002) Cerebral hemorrhage after passive anti-abeta immunotherapy. Science. 298, 1379. doi:10.1126/science. 1078259

16 Fukuchi, K., Accavitti-Loper, M. A., Kim, H. D., Tahara, K., Cao, Y., Lewis, T. L., Caughey, R. C., Kim, H. and Lalonde, R. (2006) Amelioration of amyloid load by anti-abeta single-chain antibody in alzheimer mouse model. Biochem. Biophys. Res. Commun. 344, 79-86. doi:10.1016/j.bbrc.2006.03.145

17 Zameer, A., Kasturirangan, S., Emadi, S., Nimmagadda, S. V. and Sierks, M. R. (2008) Antioligomeric abeta single-chain variable domain antibody blocks abeta-induced toxicity against human neuroblastoma cells. J. Mol. Biol. 384, 917-928. doi:10.1016/j.jmb.2008.09.068

18 Robert, R., Dolezal, O., Waddington, L., Hattarki, M. K., Cappai, R., Masters, C. L., Hudson, P. J. and Wark, K. L. (2009) Engineered antibody intervention strategies for alzheimer's disease and related dementias by targeting amyloid and toxic oligomers. Protein Eng. Des. Sel. 22, $199-208$. doi:10.1093/protein/gzn052

19 Zheng, L., Baumann, U. and Reymond, J. L. (2003) Production of a functional catalytic antibody ScFv-NusA fusion protein in bacterial cytoplasm. J. Biochem. 133, 577-581

20 Wall, J. G. and Pluckthun, A. (1999) The hierarchy of mutations influencing the folding of antibody domains in escherichia coli. Protein Eng. 12, 605-611

21 Jurado, P., de Lorenzo, V. and Fernandez, L. A. (2006) Thioredoxin fusions increase folding of single chain $\mathrm{fv}$ antibodies in the cytoplasm of escherichia coli: Evidence that chaperone activity is the prime effect of thioredoxin. J. Mol. Biol. 357, 49-61. doi:10.1016/j.jmb.2005.12.058

22 Nallamsetty, S., Kapust, R. B., Tozser, J., Cherry, S., Tropea, J. E., Copeland, T. D. and Waugh, D. S. (2004) Efficient site-specific processing of fusion proteins by tobacco vein mottling virus protease in vivo and in vitro. Protein Expr. Purif. 38, 108-115. doi:10.1016/j.pep.2004.08.016 23 Nallamsetty, S. and Waugh, D. S. (2007) A generic protocol for the expression and purification of recombinant proteins in escherichia coli using a combinatorial His6-maltose binding protein fusion tag. Nat. Protoc. 2, 383-391. doi:10.1038/nprot.2007.50

24 Gill, S. C. and von Hippel, P. H. (1989) Calculation of protein extinction coefficients from amino acid sequence data. Anal. Biochem. 182, 319-326

25 Arrondo, J. L. and Goni, F. M. (1999) Structure and dynamics of membrane proteins as studied by infrared spectroscopy. Prog. Biophys. Mol. Biol. 72, 367-405

26 Worn, A. and Pluckthun, A. (1998) Mutual stabilization of VL and VH in single-chain antibody fragments, investigated with mutants engineered for stability. Biochemistry. 37, 1312013127. doi:10.1021/bi980712q

27 Heinrikson, R. L. (1977) Applications of thermolysin in protein structural analysis. Methods Enzymol. 47, 175-189

28 Dahlgren, K. N., Manelli, A. M., Stine, W. B.,Jr, Baker, L. K., Krafft, G. A. and LaDu, M. J. (2002) Oligomeric and fibrillar species of amyloid-beta peptides differentially affect neuronal viability. J. Biol. Chem. 277, 32046-32053. doi:10.1074/jbc.M201750200

29 Lopez De La Paz, M., Goldie, K., Zurdo, J., Lacroix, E., Dobson, C. M., Hoenger, A. and Serrano, L. (2002) De novo designed peptide-based amyloid fibrils. Proc. Natl. Acad. Sci. U. S. A. 99, 16052-16057. doi:10.1073/pnas.252340199

30 Martin, C. D., Rojas, G., Mitchell, J. N., Vincent, K. J., Wu, J., McCafferty, J. and Schofield, D. J. (2006) A simple vector system to improve performance and utilisation of recombinant antibodies. BMC Biotechnol. 6, 46. doi:10.1186/1472-6750-6-46

31 Arndt, K. M., Muller, K. M. and Pluckthun, A. (1998) Factors influencing the dimer to monomer transition of an antibody single-chain fv fragment. Biochemistry. 37, 12918-12926. doi:10.1021/bi9810407

32 Sreerama, N., Manning, M. C., Powers, M. E., Zhang, J. X., Goldenberg, D. P. and Woody, R. W. (1999) Tyrosine, phenylalanine, and disulfide contributions to the circular dichroism of proteins: Circular dichroism spectra of wild-type and mutant bovine pancreatic trypsin inhibitor. Biochemistry. 38, 10814-10822. doi:10.1021/bi990516z

33 Byler, D. M. and Susi, H. (1986) Examination of the secondary structure of proteins by deconvolved FTIR spectra. Biopolymers. 25, 469-487. doi:10.1002/bip.360250307 
34 Walther, F. J., Waring, A. J., Hernandez-Juviel, J. M., Gordon, L. M., Wang, Z., Jung, C. L., Ruchala, P., Clark, A. P., Smith, W. M., Sharma, S. and Notter, R. H. (2010) Critical structural and functional roles for the $\mathrm{N}$-terminal insertion sequence in surfactant protein $\mathrm{B}$ analogs. PLoS One. 5, e8672. doi:10.1371/journal.pone.0008672

35 Jahn, T. R., Tennent, G. A. and Radford, S. E. (2008) A common beta-sheet architecture underlies in vitro and in vivo beta2-microglobulin amyloid fibrils. J. Biol. Chem. 283, 17279-17286. doi:10.1074/jbc.M710351200

36 Zandomeneghi, G., Krebs, M. R., McCammon, M. G. and Fandrich, M. (2004) FTIR reveals structural differences between native beta-sheet proteins and amyloid fibrils. Protein Sci. 13, 33143321. doi:10.1110/ps.041024904

37 Gosal, W. S., Morten, I. J., Hewitt, E. W., Smith, D. A., Thomson, N. H. and Radford, S. E. (2005) Competing pathways determine fibril morphology in the self-assembly of beta2-microglobulin into amyloid. J. Mol. Biol. 351, 850-864. doi:10.1016/j.jmb.2005.06.040

38 Naiki, H., Higuchi, K., Hosokawa, M. and Takeda, T. (1989) Fluorometric determination of amyloid fibrils in vitro using the fluorescent dye, thioflavin T1. Anal. Biochem. 177, 244-249

39 Ray, S. S., Singh, S. K. and Balaram, P. (2001) An electrospray ionization mass spectrometry investigation of 1-anilino-8-naphthalene-sulfonate (ANS) binding to proteins. J. Am. Soc. Mass Spectrom. 12, 428-438

40 McParland, V. J., Kad, N. M., Kalverda, A. P., Brown, A., Kirwin-Jones, P., Hunter, M. G., Sunde, M. and Radford, S. E. (2000) Partially unfolded states of beta(2)-microglobulin and amyloid formation in vitro. Biochemistry. 39, 8735-8746

41 Greenblatt, J., McLimont, M. and Hanly, S. (1981) Termination of transcription by nus A gene protein of escherichia coli. Nature. 292, 215-220

42 Pan, T., Artsimovitch, I., Fang, X. W., Landick, R. and Sosnick, T. R. (1999) Folding of a large ribozyme during transcription and the effect of the elongation factor NusA. Proc. Natl. Acad.

Sci. U. S. A. 96, 9545-9550

43 Martsev, S. P., Chumanevich, A. A., Vlasov, A. P., Dubnovitsky, A. P., Tsybovsky, Y. I., Deyev, S. M., Cozzi, A., Arosio, P. and Kravchuk, Z. I. (2000) Antiferritin single-chain fv fragment is a functional protein with properties of a partially structured state: Comparison with the completely folded V(L) domain. Biochemistry. 39, 8047-8057

44 Pedroso, I., Irun, M. P., Machicado, C. and Sancho, J. (2002) Four-state equilibrium unfolding of an scFv antibody fragment. Biochemistry. 41, 9873-9884

45 Umetsu, M., Tsumoto, K., Hara, M., Ashish, K., Goda, S., Adschiri, T. and Kumagai, I. (2003) How additives influence the refolding of immunoglobulin-folded proteins in a stepwise dialysis system. spectroscopic evidence for highly efficient refolding of a single-chain fv fragment. J. Biol. Chem. 278, 8979-8987. doi:10.1074/jbc.M212247200

46 Lupinek, C., Roux, K. H., Laffer, S., Rauter, I., Reginald, K., Kneidinger, M., Blatt, K., Ball, T., Pree, I., Jahn-Schmid, B., Allam, J. P., Novak, N., Drescher, A., Kricek, F., Valent, P., Englund, H. and Valenta, R. (2009) Trimolecular complex formation of IgE, fc(epsilon)RI, and a recombinant nonanaphylactic single-chain antibody fragment with high affinity for IgE. J. Immunol. 182, 48174829. doi:10.4049/jimmunol.0800726

47 Baden, E. M., Owen, B. A., Peterson, F. C., Volkman, B. F., Ramirez-Alvarado, M. and Thompson, J. R. (2008) Altered dimer interface decreases stability in an amyloidogenic protein. J. Biol. Chem. 283, 15853-15860. doi:10.1074/jbc.M705347200

48 Cerda-Costa, N., De la Arada, I., Aviles, F. X., Arrondo, J. L. and Villegas, S. (2009) Influence of aggregation propensity and stability on amyloid fibril formation as studied by fourier transform infrared spectroscopy and two-dimensional COS analysis. Biochemistry. 48, 10582-10590. doi:10.1021/bi900960s

49 Worn, A. and Pluckthun, A. (1999) Different equilibrium stability behavior of ScFv fragments: Identification, classification, and improvement by protein engineering. Biochemistry. 38, 8739-8750. doi:10.1021/bi9902079

50 Cheng, I. H., Scearce-Levie, K., Legleiter, J., Palop, J. J., Gerstein, H., Bien-Ly, N., Puolivali, J., Lesne, S., Ashe, K. H., Muchowski, P. J. and Mucke, L. (2007) Accelerating amyloid-beta fibrillization reduces oligomer levels and functional deficits in alzheimer disease mouse models. J. Biol. Chem. 282, 23818-23828. doi:10.1074/jbc.M701078200 
Table 1: Band decomposition of FTIR amide I band of scFv-h3D6 acquired at different temperatures.

\begin{tabular}{|l|r|r|r|r|r|r|}
\hline \multirow{2}{*}{ Secondary structure } & \multicolumn{2}{|c|}{$25^{\circ} \mathrm{C}$} & \multicolumn{2}{|c|}{$37^{\circ} \mathrm{C}$} & \multicolumn{2}{c|}{$60^{\circ} \mathrm{C}$} \\
\cline { 2 - 7 } & $\begin{array}{l}\text { Center } \\
\left(\mathrm{cm}^{-1}\right)\end{array}$ & $\%$ & $\begin{array}{l}\text { Center } \\
\left(\mathrm{cm}^{-1}\right)\end{array}$ & $\%$ & $\begin{array}{l}\text { Center } \\
\left(\mathrm{cm}^{-1}\right)\end{array}$ & $\%$ \\
\hline High Freq. antip. $\beta$-sheet & 1681 & 9 & 1683 & 4 & 1683 & 4 \\
\hline High Freq. loops/turns & - & - & - & - & 1671 & 11 \\
\hline Low Freq. loops/turns & 1660 & 30 & 1661 & 35 & 1662 & 6 \\
\hline$\alpha$-helix & - & - & - & - & 1653 & 15 \\
\hline Random coil & - & - & - & - & 1644 & 14 \\
\hline Low Freq. antip. $\beta$-sheet & 1636 & 60 & 1636 & 59 & 1636 & 16 \\
\hline Worm-like fibril & - & - & - & - & 1626 & 23 \\
\hline Amyloid fibril & $1612^{\mathrm{a}}$ & 1 & 1616 & 1 & 1615 & 9 \\
\hline
\end{tabular}

(a) This band, although quantitatively negligible, could also be assigned to amino-acid side-chains. 


\section{FIGURE LEGENDS}

Figure 1. Secondary structure and thermal denaturation of scFv-3D6h. (A) Far-UV CD-spectra at different temperatures. The spectrum at $25^{\circ} \mathrm{C}$ shows two ellipticity minima $(218 \mathrm{~nm}$ and $230 \mathrm{~nm})$, an ellipticity maximum $(200 \mathrm{~nm})$ and a positive shoulder $(237 \mathrm{~nm})$. This particular shape of the spectra is lost at $60^{\circ} \mathrm{C}$ in favor of a canonical $\beta$-sheet conformation (ellipticity minimum at $215 \mathrm{~nm}$ ), which is maintained at $90^{\circ} \mathrm{C}$ and after renaturation (not shown). (B-D) Band decomposition of the FTIR amide I spectra at relevant temperatures. (B) $25^{\circ} \mathrm{C}$. (C) $37^{\circ} \mathrm{C}$. (D) $60^{\circ} \mathrm{C}$. Decomposition at $25^{\circ} \mathrm{C}$ and $37^{\circ} \mathrm{C}$ generated four components, whereas at $60^{\circ} \mathrm{C}$ eight components contributed to the spectrum (see Table 1). The dotted line indicates the $1626 \mathrm{~cm}^{-1}$ component. (E) Thermal denaturation followed up by CD (ellipticity at $218 \mathrm{~nm}$ ). (F) Thermal denaturation followed up by tryptophan fluorescence $(338 \mathrm{~nm})$ and turbidity (OD at $350 \mathrm{~nm}$ ). Solid-black circles, fluorescence of protein at $20 \mu \mathrm{M}$; Solid-gray squares, fluorescence of protein at $2 \mu \mathrm{M} \times 10$; Open circles, turbidity of protein at $20 \mu \mathrm{M}$.

Figure 2. MTT toxicity assays with the SH-SY5Y human neuroblastoma cell-line. (A) Toxicity induced by different concentrations of the $A \beta_{1-42}$ peptide. * Significant versus $0 \mu \mathrm{M} A \beta_{1-42}(\mathrm{~B})$ Recovery of cell viability in the presence of $10 \mu \mathrm{M}$ of $\mathrm{A} \beta_{1-42}$ peptide by adding different concentrations of scFv- h3D6. S, $10 \mu \mathrm{M} \mathrm{scFv}$-h3D6 alone (without $\mathrm{A} \beta$ peptide); B, buffer (without $\mathrm{A} \beta$ peptide and $\mathrm{scFv}) .{ }^{*}$ Significant versus $0 \mu \mathrm{M} \mathrm{scFv}$-h3D6. The error bars indicate SEM. ${ }^{*} \mathrm{p}<0.068$ using the Wilcoxon signed-rank test for four independent experiments (six replicas for each condition per experiment).

Figure 3. Transmission electron micrographs of $100 \mu \mathrm{M} \mathrm{A} \beta_{1-42}$ (A), $100 \mu \mathrm{M}$ scFv-h3D6 (B), $100 \mu \mathrm{M}$ scFv-h3D6 in the absence of DMSO (see Experimental Section) (C), and $100 \mu \mathrm{M} A \beta_{1-42}$ plus $100 \mu \mathrm{M}$ scFv-h3D6 (D), at different temperatures. (A) The cytotoxic oligomers of the A $\beta$ peptide are visualized at $37^{\circ} \mathrm{C}$, and heating at higher temperature is mandatory to obtain amyloid fibrils. (B) ScFv-h3D6 does not form WL fibrils in the presence of DMSO. (C) ScFv-h3D6 in the absence of DMSO forms small oligomers at $37^{\circ} \mathrm{C}$, and at $60^{\circ} \mathrm{C}$ (where the thermal-induced intermediate state of scFv-h3D6, I-state, is more populated) initiates the formation of worm-like (WL) fibrils; these WL fibrils are better structured after treatment at $90^{\circ} \mathrm{C}$. (D) The $\mathrm{A} \beta_{1-42}: \mathrm{scFv}-\mathrm{h} 3 \mathrm{D} 6$ complex directly forms WL fibrils at $37^{\circ} \mathrm{C}$ and heating disrupts them, allowing large amyloid fibrils and oligomers to form.

Figure 4. Fluorescence-based aggregation assays. (A-B) Different temperature treatments used in this work. (A) ThT (482nm). (B) ANS (470nm). The error bars indicate SEM. (C-D) Binding upon thermal denaturation. (C) ThT (482nm). (D) ANS (470nm).

Figure 5. Energy diagrams for the aggregation pathways of the $\mathrm{A} \beta_{1-42}$ peptide, scFv-h3D6, and the $\mathrm{A} \beta_{1-42}: \mathrm{scFv}-\mathrm{h} 3 \mathrm{D} 6$ complex. (A) At $37^{\circ} \mathrm{C}$ (continuous arrows), the $\mathrm{A} \beta$ peptide follows the amyloid pathway through the formation of cytotoxic oligomers $(\mathrm{O})$ and scFv-h3D6 (S) follows the worm-like (WL) pathway through the formation of non-cytotoxic oligomers (sO). Temperature treatment (dotted arrows) is necessary to convert oligomers of $\mathrm{A} \beta$ into amyloid fibrils (AF) and sO of scFv-h3D6 into WL fibrils, in the latter case in the absence of DMSO traces. (B) The A $\beta_{1-42}: \mathrm{scFv}$-h3D6 complex directly forms WL fibrils, and its disruption by temperature (dotted arrows) generates $\mathrm{sO}$ of scFvh3D6, whereas the A $\beta$ peptide "jumps" into the amyloid fibril pathway, forming oligomers and AF. 
Biochemical Journal Immediate Publication. Published on 18 Apr 2011 as manuscript BJ20101712

Figure 1

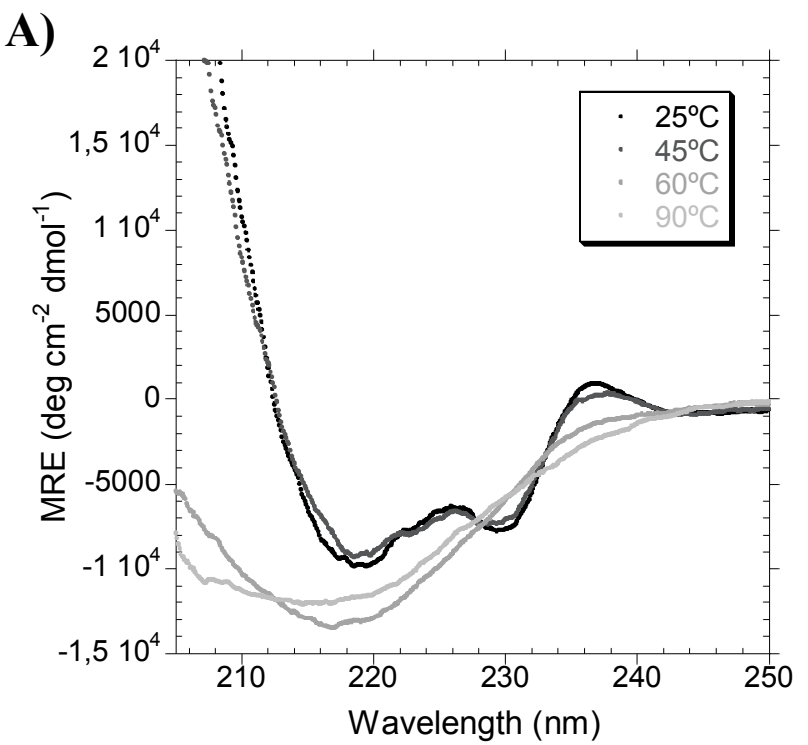

B)

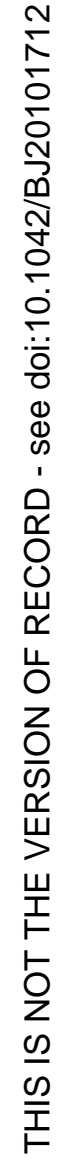

C)

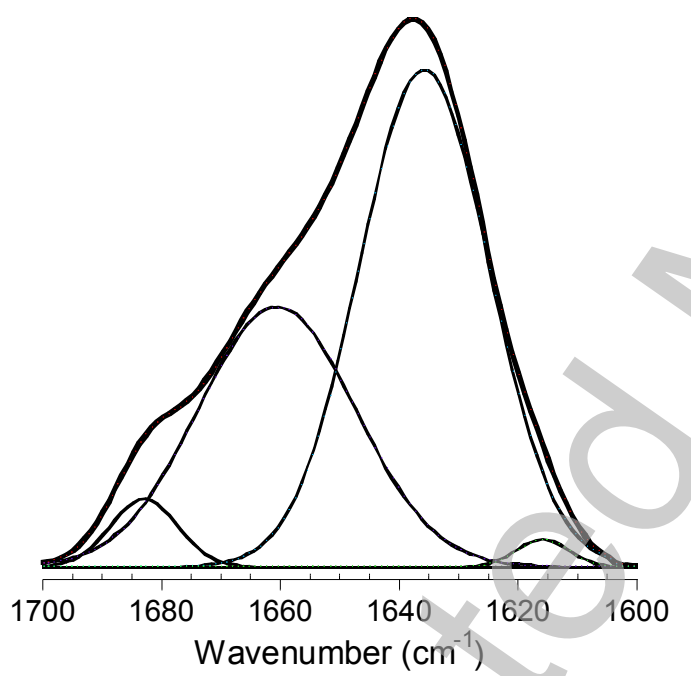

D)
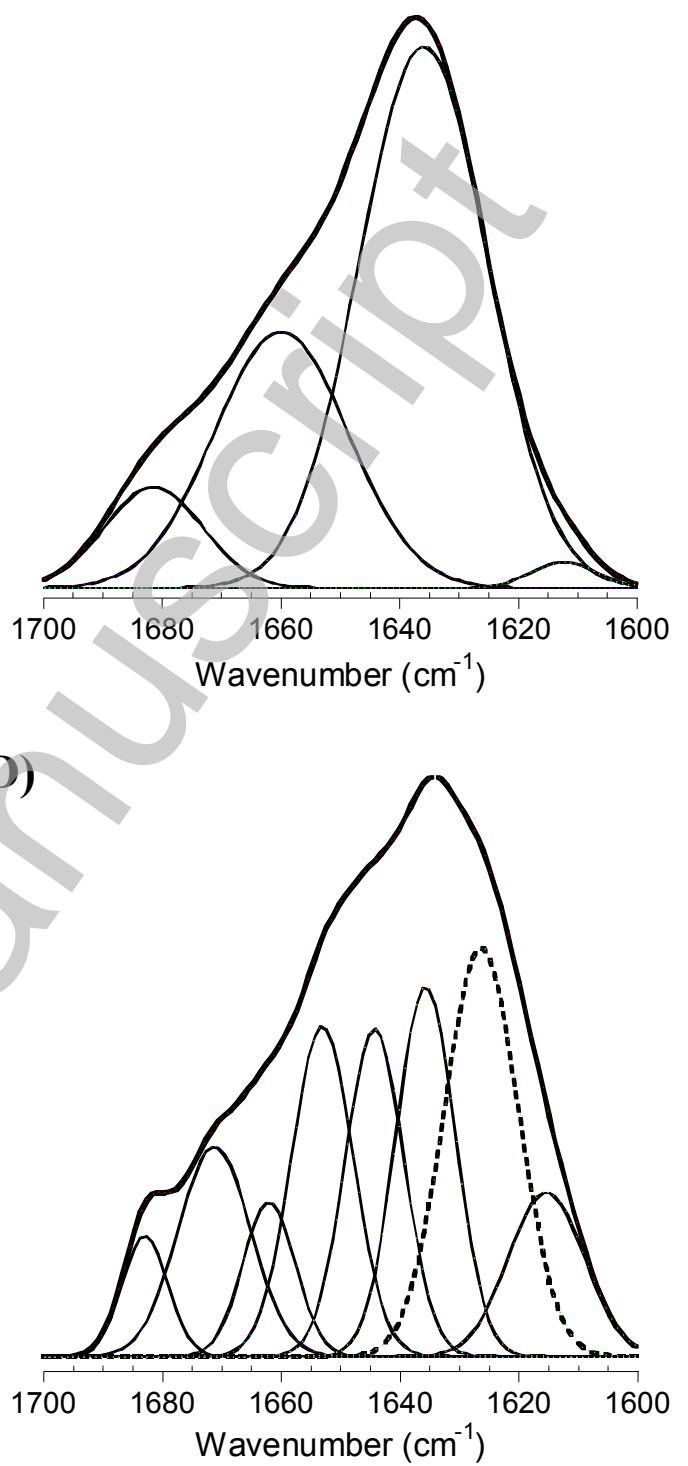

E)

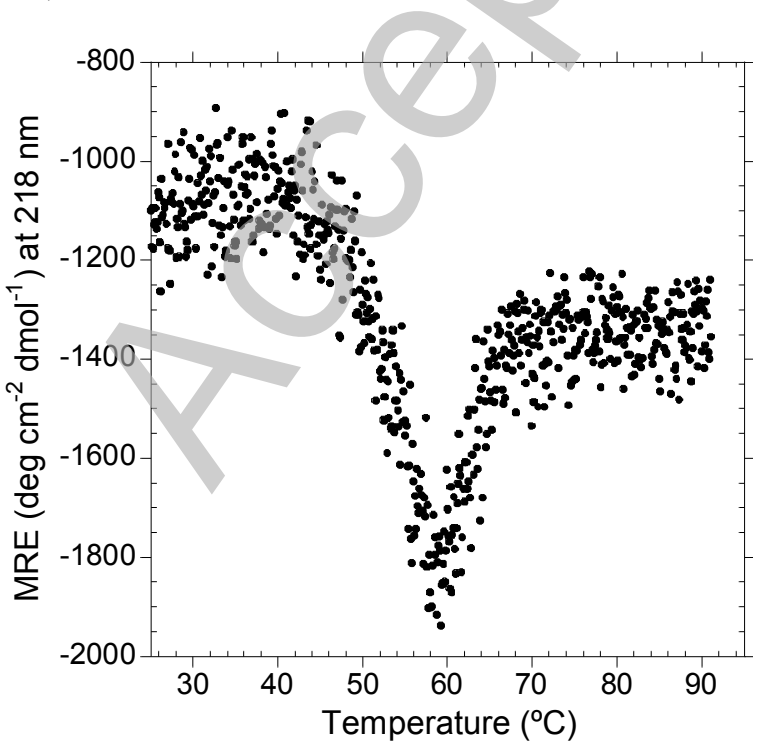

F)

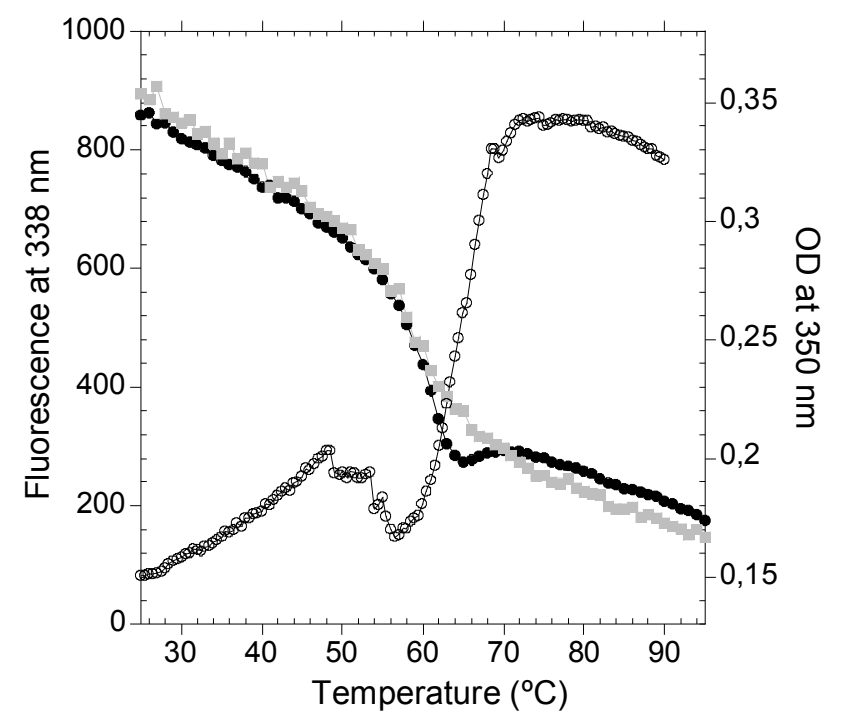

Licenced copy. Copying is not permitted, except with prior permission and as allowed by law.

(C) 2011 The Authors Journal compilation (c) 2011 Portland Press Limited 
Figure 2

A)

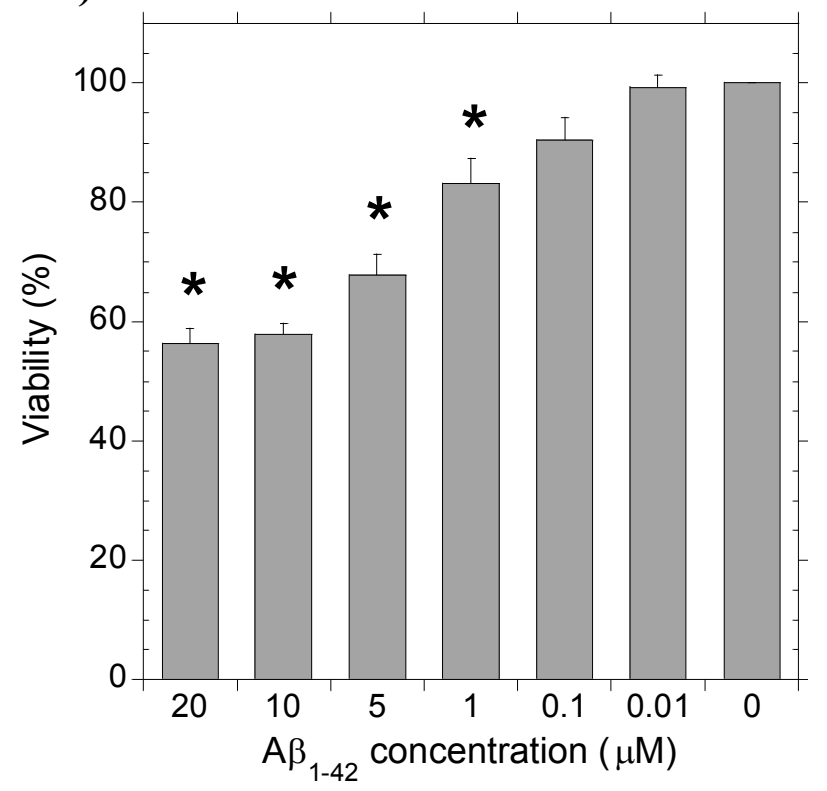

B)

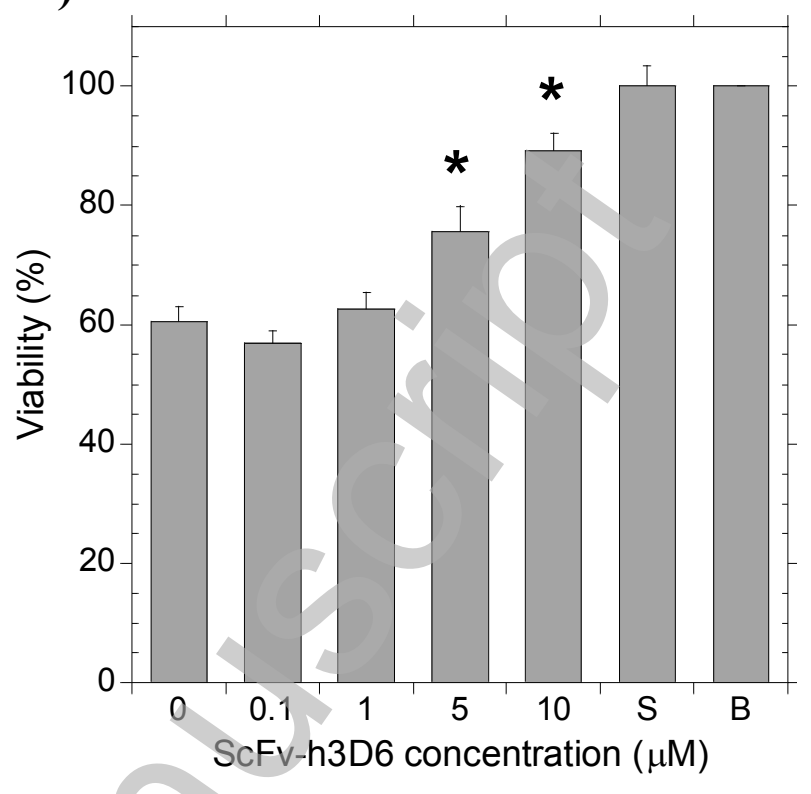

 
Biochemical Journal Immediate Publication. Published on 18 Apr 2011 as manuscript BJ20101712

Figure 3
(A) $\mathrm{A} \beta 100 \mu \mathrm{M}$
(B) ScFv $100 \mu \mathrm{M}$
(C) ScFv $100 \mu \mathrm{M}$,
(D) $\mathrm{A} \beta 100 \mu \mathrm{M}$

no DMSO traces

+ scFv $100 \mu \mathrm{M}$

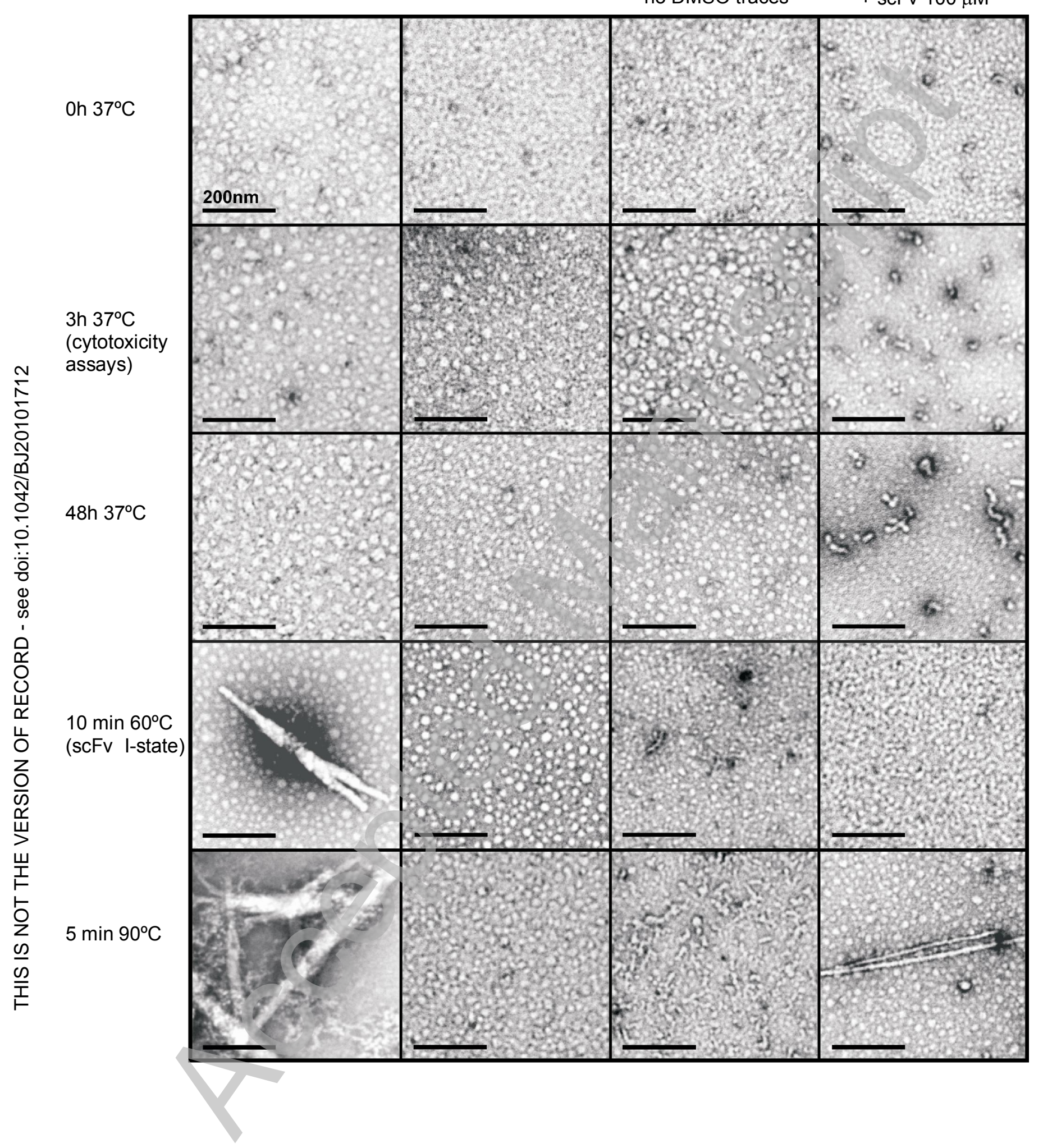

Licenced copy. Copying is not permitted, except with prior permission and as allowed by law. (C) 2011 The Authors Journal compilation @ 2011 Portland Press Limited 
Figure 4

A)

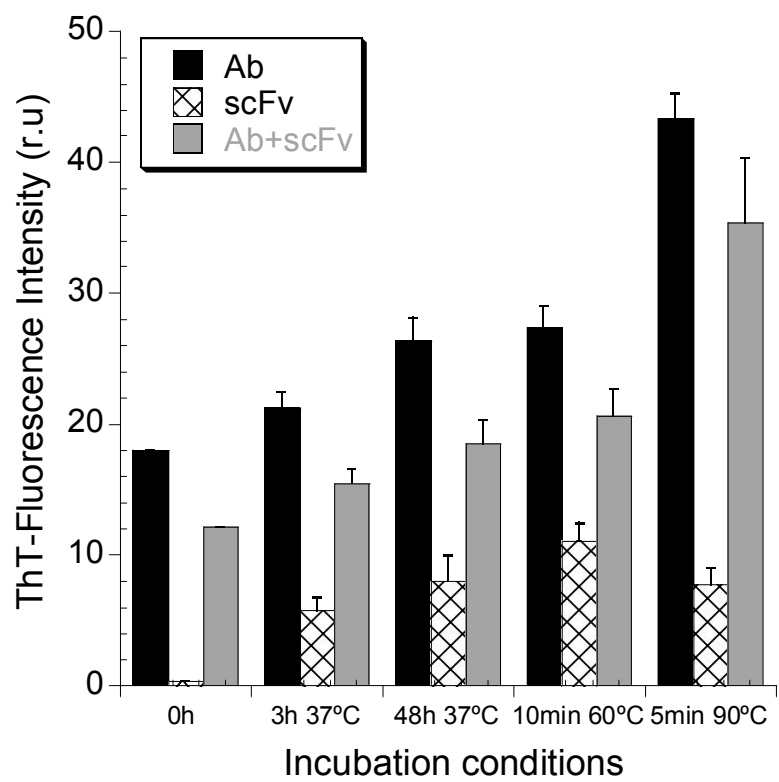

C)

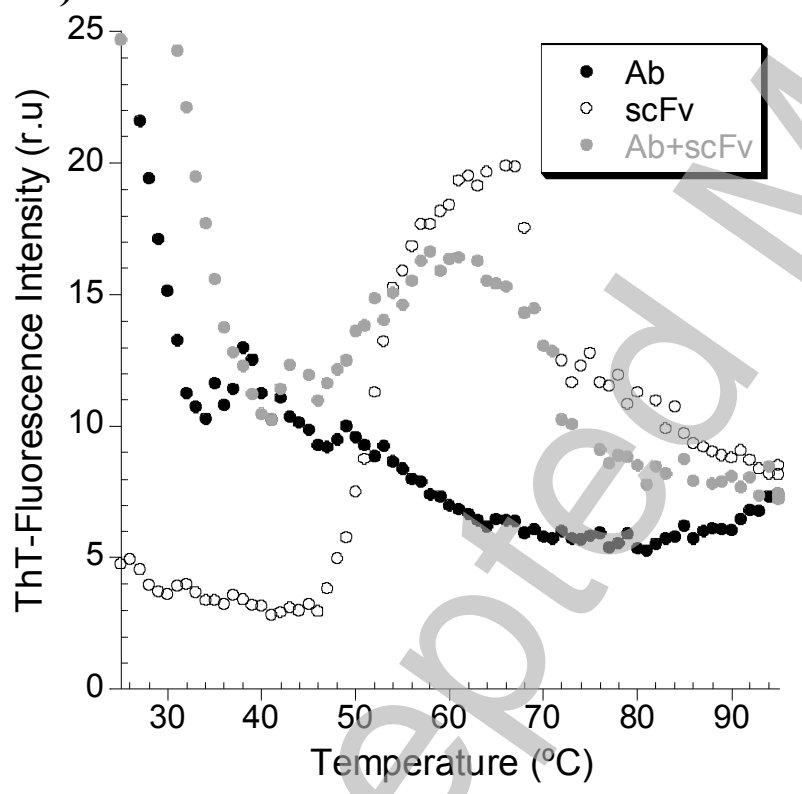

B)

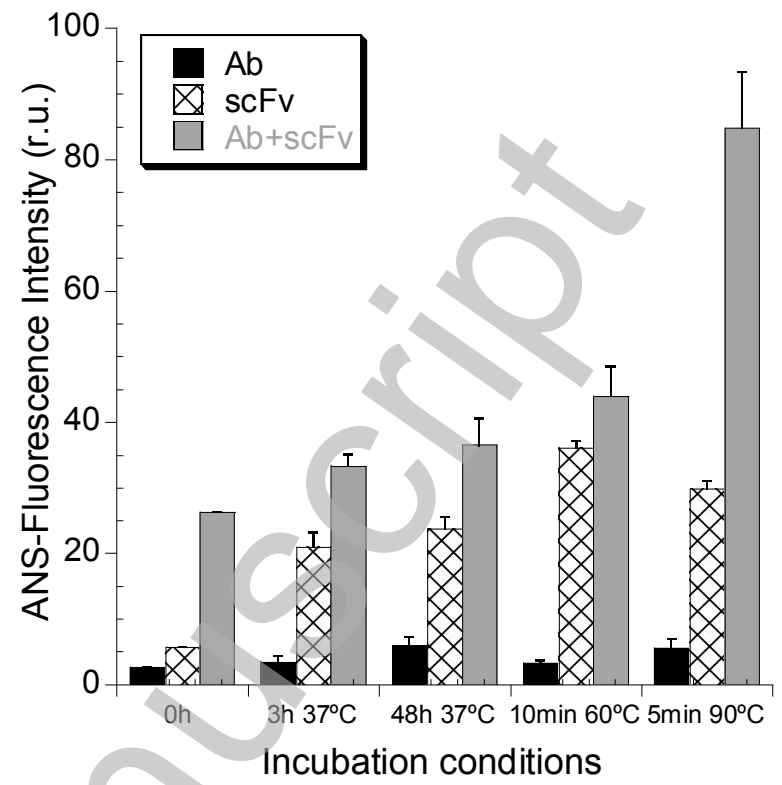

D)

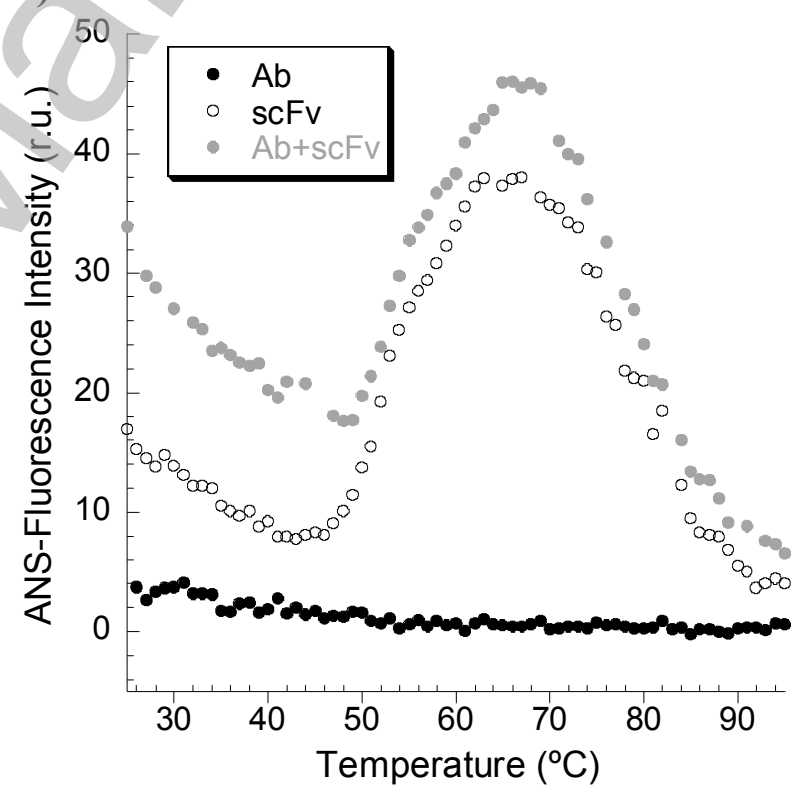


Figure 5

A)

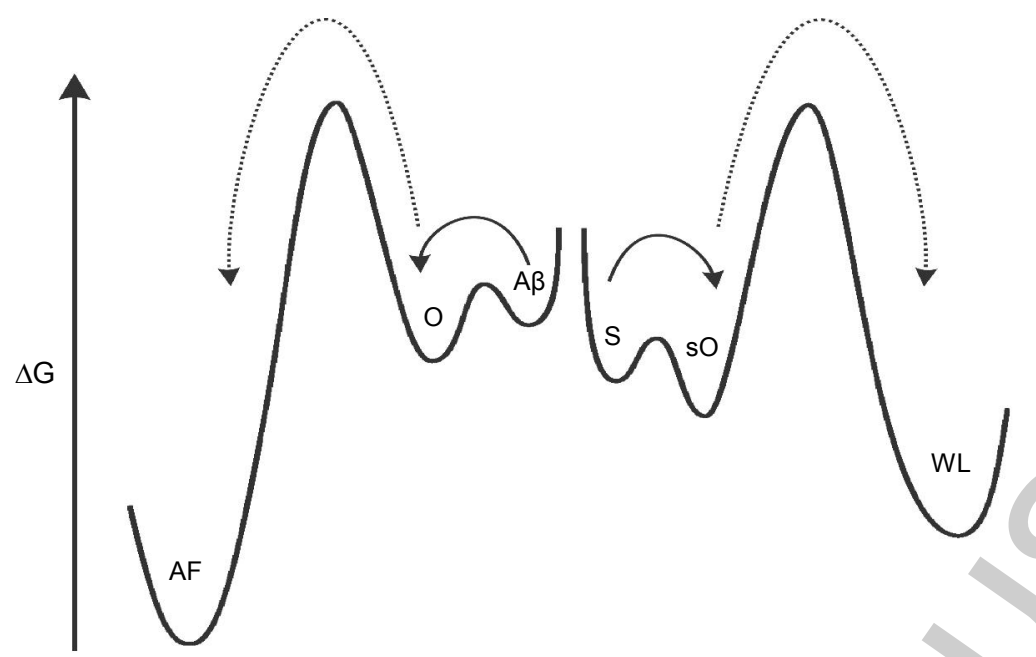

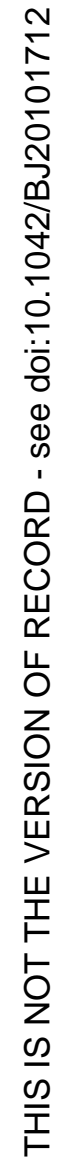

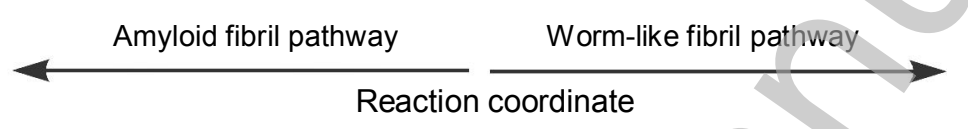

B)
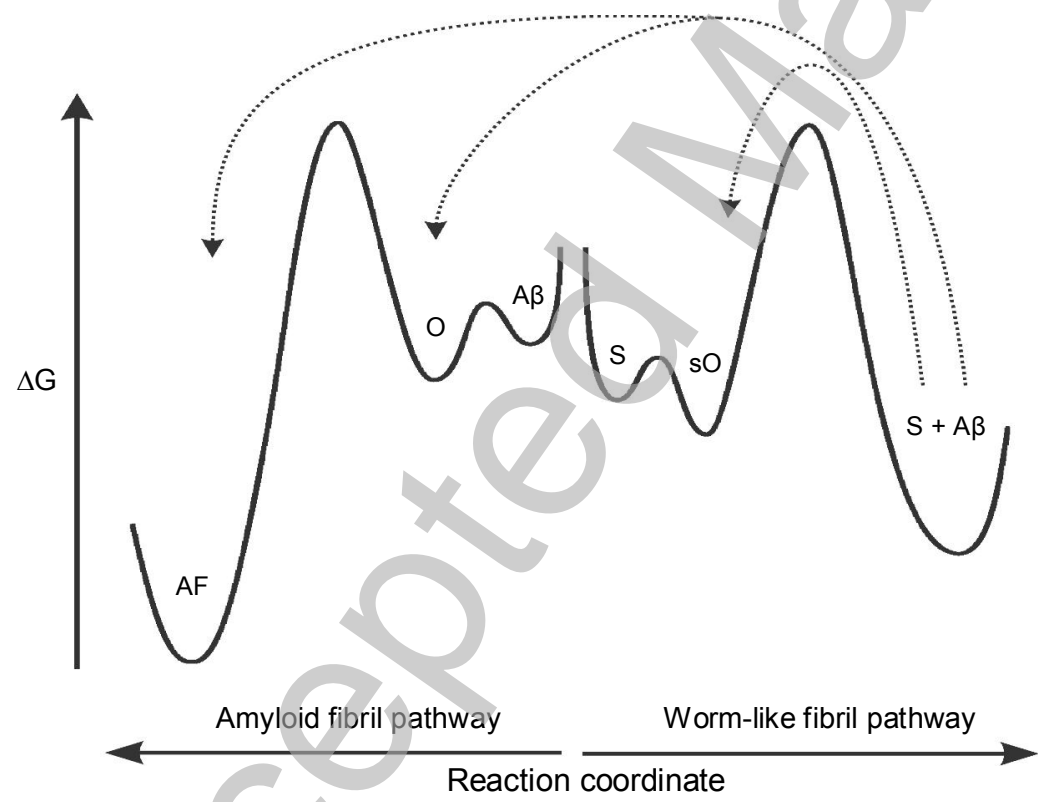